\title{
PEDRO VENTURA DE PUGA, ÚLTIMO SEÑOR DE LA CASA DE FONTEFIZ
}

\author{
PAZ LEIRÓS DE LA PEÑA
}

\begin{abstract}
Resumen
Este trabajo está basado en la documentación de la Casa de Fontefiz, conservada en al AHPOR. Los documentos abarcan desde el siglo XVI al XIX y nos aportan información sobre el patrimonio de la Casa, su posición social y las actividades políticas de Pedro Ventura de Puga en la primera mitad del siglo XIX. La primera parte se centra en el origen y evolución del patrimonio, modo de vida, abusos de la hidalguía en el plano social y sexual y las dificultades para mantener el stuatus social. La segunda parte tiene como protagonista a Pedro Ventura de Puga, su participación en la Guerra de la Independencia y en la construcción del estado liberal. Es una figura clave para entender la adaptación de la hidalguía a una época de cambios políticos y de pervivencias sociales y económicas. La defensa de la Constitución y la participación en el régimen liberal es compatible con el mantenimiento de una econocmía basada en el conbro de rentas y los títulos de nobleza. Pedro Ventura de Puga se inscribe políticamente en el liberalismo moderado.
\end{abstract}

\section{Palabras clave}

Hidalguía, rentas, foros, genealogía, Guerra de la Independencia

\begin{abstract}
This paper is based on documentation from Casa de Fontefiz kept in the AHPOR. The documents cover the period from the sixteenth to nineteenth century and provide information about the patrimony of the house, its social position and the political activities of Pedro Ventura de Puga during the firts half of the nineteenth century. The first part is focused on the origin and evolution of patrimony, way of living, nobility abuses (including social and sexual aspects), and the difficulties to keep the social status. In the second part, Pedro Ventura plays the main role: his participation in the War of Independence and the building of the liberal state. He is a relevant character to undestand the adaptation of nobility to an age of political changes and social ad economical survivals. The defense of the constitution and his participation in the liberal regime is compatible with the maintenance of a economy based on the collection of taxes and nobility titles. Pedro Ventura is politically registered as a moderate liberalist,
\end{abstract}

\section{Keywords}

Nobility, rents, "foros", genealogy, War of Independence. 


\section{INTRODUCCIÓN: LA HIDALGUÍA EN UNA ÉPOCA DE CAMBIOS}

Pedro Ventura de Puga es el último señor de la Casa de Fontefiz. Con él se pone fin a una época de hidalgos, pazos, y una forma de vida centrada en el medio rural con una economía basada en la percepción de rentas y un sistema jurídico social que distingue entre privilegiados y no privilegiados.

La hidalguía, grupo social determinante en Galicia, nace con el Antiguo Régimen y, gracias a la apropiación de buena parte del excedente agrario, su situación económica es holgada, muestra de ello son los numerosos pazos de la geografía gallega. Durante más de tres siglos se mantiene y prolonga su existencia a lo largo del siglo XIX, mientras perduren las bases de su sistema económico. Su papel es, pues, de una gran relevancia ya que no sólo controla importantes recursos económicos sino que también accede al poder político. ${ }^{1}$

El último señor de Fontefiz vive entre 1875 y 1866, fines del siglo XVIII y buena parte del XIX. Con él desaparece la Casa de Fontefiz (integrada a partir de su muerte en el Marquesado de Leis) y una forma de vida caracterizada en el predominio de este grupo. El último señor del pazo asiste a la crisis de un sistema que está en decadencia pero, aún resistente, subsistirá después de su muerte.

Es, también un ejemplo de adaptación a una situación de cambio:

Vive el conflicto bélico de la guerra de Independencia a principios del siglo XIX y el paso de una sociedad rural y tradicional a otra de carácter liberal y más urbana.

La legislación liberal parece no chocar demasiado con los intereses de la hidalguía gallega, o, por lo menos, Pedro Ventura sabe sacar partido de los cambios.

La figura de Pedro Ventura destaca por su intervención en la guerra de Independencia y por su actividad política posterior. Su participación en la vida política, su pensamiento económico y sus recursos económicos, permitirán completar este cuadro de la hidalguía gallega.

\footnotetext{
${ }^{1}$ Eiras Roel: Régimen Subforal e hidalguía intermediaria. Prólogo a M.C. Quintans Vázquez en "El Dominio de San Martin Binario ante la desamortización. Universidad de Santiago, 1972.

García Lombardero: La agricultura y el estancamiento económico de Galicia en la España del Antiguo Régimen, 1973.

Angel García Sanz: Las tribulaciones de un noble castellano en la crisis del A.R.: D. Luis Domingo de Contreras y Escobar, V Marqués de Lozoya (1779-1838), en Historia económica y pensamiento social, Madrid 1983.
} 
Veamos cuál es el escenario de esta historia:

Fontefiz se encuentra situado en el valle de A Peroxa, cerca de un pequeño afluente del Miño, el río de la Barra. Estamos al norte de Ourense , a pocos kilómetros de la ciudad.

Pedro Ventura reside en el pazo de Fontefiz con su mujer, $\mathrm{D}^{\mathrm{a}} \mathrm{M}^{\mathrm{a}}$ Antonia de Puga y sus dos hijas, dedicado a "mis negocios domésticos única causa de mi vida"

El pazo, construido en sillares de granito, presenta planta en forma de U con patio interior, escudo, solana, chimenea de más de seis metros de altura y capilla con retablo barroco.

Pertenece administrativamente al municipio de Coles y a la parroquia de La Barra. Actualmente, después de su compra por parte del Ministerio de Agricultura en 1944 , se ha convertido en un centro de selección de ganado bovino. ${ }^{2}$

\section{ORIGEN DE LA CASA DE FONTEFIZ}

¿Cual es el origen de esta casa? La documentación de la casa es abundante con respecto a sus orígenes. La conservación de estos documentos es importante para poder demostrar la situación de privilegio de sus dueños, por eso, aparte de los datos de tipo económico, encontramos documentos sobre la genealogía de la casa. $^{3}$

El topónimo de Fontefiz aparece por primera vez en el siglo X en la carta de fundación del monasterio de monjas benedictinas de San Miguel de Bóveda con el nombre de "Casal de Fonte Felici"(Ferro Couselo, 1965).

En 1597 en monasterio de San Clodio, al cual se había unido anteriormente el de San Miguel de Bóveda, hace foro de este lugar a Gregorio de Nóboa, fundador del linaje de la Casa de Fontefiz.

El lugar de Fontefiz se componía en estos momentos de: dos casas, dos "cortes" para el ganado, dieciséis cavaduras de viña, dieciséis fanegas de pan y un soto.

\footnotetext{
2 Jesús Ferro Couselo: "Ayer y hoy del Pazo de Fontefiz”, Ourense 1965. Ma Teresa Rivera Rodríguez: Los Pazos Orensanos, 1981.

${ }^{3}$ Sobre el origen y genealogía de la casa de Fontefiz: Testamento de Gregorio de Nóvoa 1621, el original en C9633 $\mathrm{n}^{\circ} 165$, y la copia del año 1700 en C9630 $\mathrm{n}^{\circ} 4$ bis.

Memorial de bienes que fincaron de Gregorio de Nóboa y su mujer, 1628, AHPOR, C9633 nº 174.

Memorial de 1668, AHPOR C9633.
} 
Sin embargo, Gregorio de Nóboa no residió en Fontefiz sino en San Ginés de la Peroja ${ }^{4}$, donde nació y fue enterrado. Aquí es donde vamos a ver el origen del patrimonio de la Casa, que surge a fines del siglo XVI y perdura hasta el siglo XX.

Gregorio de Nóboa es hijo natural de Pedro de Bóveda de Nóboa, abad de San Ginés y de Francisca Vázquez de Puga, sobrina del anterior abad de San Ginés, Pedro Vázquez de Puga, según indica la "Información de nobleza de Gregorio de Nóboa"en 1597:

Pedro de Bóveda tenía dos beneficios y "los comía y gozaba con las primeras hordenes (...) por ser antes del Santo Concilio y en este tiempo se murió Pedro Vázquez de Puga abad que fue del beneficio de San Ginés el cual dejo por su heredero a dicho Pedro de Boveda". Y también le dejó a su sobrina, Francisca Vázquez ${ }^{5}$ y "con ella tuvo amistad carnal". De esta relación nacieron cuatro hijos: Violante de Nóboa, Francisco de Nóboa, el "maestro" Tristán y Gregorio de Nóboa, a los cuales "el dicho Pedro de Bóveda los crió en su casa y los alimentó y bautizo por suyos y les llamaba hijos".

Así pues, el origen se remonta a fines del siglo XVI y la procedencia de su fundador es claramente clerical.

Gregorio de Nóvoa se casa dos veces. La primera con Catalina López de Moure, de San Salvador de Chantada, de la que tuvo tres hijos: Pedro de Bóveda, que murió siendo estudiante en Santiago, y Jerónimo y Melchor de Nóboa "los cuales fueron a servir al rey Don Felipe segundo y nunca mas parecieron y tengo noticia que son muertos".

Su segundo matrimonio, en 1583, con Inés Díaz de Cadórniga que aporta una dote de 1200 ducados, cuatro veces más que la de su anterior mujer. Es hija de Elvira Díaz de Cadórniga quien "mando hacer a su costa" el coro de la iglesia de Santa

\footnotetext{
${ }^{4}$ Gregorio de Nóboa vincula sus bienes en 1596. Al año siguiente realiza una "información de nobleza". Muere en 1623 y será enterrado en la iglesia de San Ginés de la Peroja donde se puede ver la siguiente inscripción en su sepultura:

Estas armas y sepultura

contigua a esta pared lado

del ebangelio son de la casa

de S. Gines y las dotó Greg. ${ }^{\circ}$

de Noboa de $V^{a} M$. En $\operatorname{can}^{o} I^{o} M^{o}$ de

$V^{o}$ anual año de 1585 y lo pae

DM a la casa a esta fabrica

${ }^{5}$ Francisca Vázquez, madre de Gregorio de Nóvoa, deja dos lugares avinculados que forman el núcleo inicial del patrimonio en 1611: el lugar de Souto (Fra. de Boimorto) en Villamaría y el lugar de San Ginés en la Peroja.
} 
María de la Barra, según vemos hoy en la inscripción de la propia iglesia. Gregorio de Nóvoa hace una "Información de Nobleza" en 1597.

Gregorio de Nóboa vivió en San Ginés de la Peroja y allí fue enterrado en 1621 según consta en la inscripción de su sepultura.

De sus cinco hijos, es Elvira Díaz de Cadórniga, de igual nombre que su abuela, la que recibe en dote el lugar de Fontefiz en 1606 y lo convierte en casa solariega ${ }^{6}$.

Le sucede Benita de Nóboa, casada con Francisco de Puga Arias y Nóboa. Su hijo mayor, Antonio de Puga (nace en 1645 y hace testamento en 1709) será el heredero.

En el siglo XVIII, Rodrigo de Puga, su hijo y heredero, consigue el directo dominio que el monasterio de San Clodio aún tenía sobre el lugar de Fontefiz.

La descendencia sigue la línea masculina con Pedro Ventura de Puga, abuelo de nuestro protagonista. Se casa con Constanza Rajó y Suárez de Deza de la casa de Argeriz en el valle de Lemos. Dos de sus hijas, Juana y Teresa, renuncian a sus legítimas y entran en el convento del Santo Espíritu en Astorga. Hace testamento a los noventa y cinco años en 1794.

Le sucede Ramiro de Puga quien casa con Manuela Gómez y Suárez de la casa de Entrambosríos y Pardavedra. Muere a principios del siglo XIX.

Pedro Ventura de Puga (1775-1866), de igual nombre que su abuelo, es su heredero y el último señor de Fontefiz. Su mujer es $\mathrm{M}^{\mathrm{a}}$ Antonia de Puga del Pazo de Santa María de Augas Santas. De sus dos hijas sólo tenemos noticias de M $^{\mathrm{a}}$ Manuela , quien se casa con el marqués de Leis, José $\mathrm{M}^{\mathrm{a}}$ Montenegro Gago Pimentel y España.

\footnotetext{
${ }^{6}$ Aunque Ferro Couselo adjudica a Gregorio de Nóvoa la fundación de Fontefiz hay una clara línea de descendencia femenina que se inicia con su segunda mujer Inés Díaz de Cadórniga y sigue con su hija, Elvira Díaz de Cadórniga, quien convierte Fontefiz en casa solariega.

Línea de descendencia femenina : desde Inés Díaz de Cadórniga que en 159- hace escritura de fundación del vínculo y cuyo marido, Gregorio de Novoa, se afana en consolidar su situación de noble. (Información de nobleza de Gregorio de Novoa Villamaría, 1597. Copia del año 1700. Esta Información se extrae a partir de una querella en la que Gregorio de Novoa y su hemano Francisco, acusan a un criado del primero de dejar preñada a una sobrina del mismo y por ello es condenado a doce años de galeras.

Elvira Díaz de Cadórniga aparece en el Memorial de 1668 como sucesora de su madre: "Si saben que dicha Inés Díaz de Cadórniga estubo casada con $\mathrm{Greg}^{\circ}$ de Noboa Villamarin legitimamte. la cual hico vinculo y mayorazgo de dichos vienes que llevaba a su muerte y del tercio y quinto (...) por su hija legítima a Elvira Díaz de Cadórniga que fue heredera de dicha su madre y sucesora en el vínculo por aver muerto sin sucesión legitima Jvn y $\mathrm{Greg}^{\circ}$ de Noboa sus hermanos hijos tambien de la dicha fundadora”. Memorial de 1668 AHPOR C9633 n 130. Ver Cuadro no 1.
} 


\section{PATRIMONIO Y MODO DE VIDA}

Tenemos pocos datos para poder conocer el modo de vida y menos aún la mentalidad de los hombres o mujeres protagonistas de esta casa hidalga. Sin embargo, es posible aproximarse a su situación económica y constatar sus preocupaciones y modo de pensar en algunos aspectos. Contamos con la relación de sus bienes muebles, otra documentación e incluso algún testimonio literario.

El patrimonio de Fontefiz se forma a lo largo de tres etapas:

La formación del dominio hasta el primer tercio del siglo XVII: desde fines del siglo XVI a principios del XVII, cuando Gregorio de Nóvoa protagoniza la irresistible ascensión (el patrimonio aumenta en un $200 \%$ con respecto al núcleo inicial. en lo que se refiere a los cereales) Dos matrimonios con importantes dotes, compras, demandas, pleitos y despojos (a veces en alianza con el clero) explican este incremento. Este patrimonio hidalgo formado a partir de bienes eclesiásticos y de la compra a campesinos, utilizando todo tipo de artimañas "legales". 7

La segunda etapa comprende los dos tercios restantes del siglo XVII y todo el siglo XVIII, es la época de consolidación ${ }^{8}$. Y la tercera abarca el siglo XIX, decadencia y reubicación de la hidalguía. Son tiempos de cambio.

El patrimonio está formado fundamentalmente por rentas que se perciben en cuatro municipios: Villamarín, A Peroxa, Carballedo y Coles. Las rentas proceden en su mayoría de entidades eclesiásticas. Incluso el lugar de Fontefiz es dominio directo del Monasterio de San Clodio. ${ }^{9}$

\footnotetext{
${ }^{7}$ No en balde se queja Gregorio de Nóvoa en su testamento de lo mucho que ha gastado en pleitos: " con mis pleitos que me pusieron algunas personas por defender mi persona y acienda gaste mucho". O intenta solucionar algún abuso cometido anteriormente: "aunque Gabriel Pereyra me vendió las dos anegas de pan de renta en el lugar de Gosende no le di dinero alguno porque hubo respecto a muchas amistades que lo avia hecho y tengo escrúpulo de conciencia mando se le den a sus herederos diez ducados". AHPOR, Testamento de Gregorio de Novoa (Copia de 1700).

${ }^{8}$ Lo característico de esta etapa son las compras de parcelas o heredades de reducida extensión en tierras próximas a Fontefiz. La mayoría de estas compras se realizan coincidiendo con las crisis de subsistencia, en los primeros años del siglo XVIII y entre 1763-1764. Hay una relación entre el aumento de ventas y el hambre. Se compran tierras al campesinado aprovechando las dificultades del mismo. Pegerto Saavedra analiza la relación entre años difíciles y aumento del número de ventas: "Un aspecto de las crisis de subsistencias en la Galicia del Antiguo Régimen: las ventas de tierras", en La Historia social de Galicia...1981.

${ }^{9}$ Se trata, como señala Ramón Villares, del reparto del excedente agrario entre los grupos del bloque dominante: el clero y a su costa la hidalguía. "La propiedad de la tierra en Galicia 1500-1936", Madrid 1982.
} 
¿Cuáles son los bienes de los primeros titulares de la casa de Fontefiz?

Según el Memorial de $1628^{10}$, su nivel de vida no debía ser muy elevado, más bien estaría cerca del de un campesino acomodado que de un noble.

Los bienes de Francisca Vázquez y de su hijo ascienden a 998 ducados, pero si restamos los 600 ducados en que se valora la cosecha (más de 120 moyos y 60 anegas que quedaron a la muerte de Gregorio de Noboa Cadórniga) nos quedamos tan solo con 398 ducados, de los cuales 200 es el valor del ganado (incluyendo un cuartago con arreos), así que el resto se reparte en:

- ajuar de la casa: . . . . . 120 ducados

- aperos de labranza: . . . . . 28 ducados

- muebles: ........... 30 ducados

“con más una escopeta, cuatro lanzas y dos espadas y muchos vestidos". El ajuar se reduce a ropa de cama: colchones, sábanas, mantas y almohadas y otros objetos. Los muebles consisten en un escritorio un "almario", dos bancos "de espaldar", cuatro mesas, dos escabeles, dos sillas y cuatro camas. Vemos pues, la modestia de la casa. Sólo dos notas parecen diferenciarla de la de un campesino acomodado: la existencia de un caballo mediano (cuartago) y las armas. No hay sin embargo joyas ni otros objetos valiosos.

Con Gregorio de Noboa, los bienes muebles se triplican con respecto a los de su madre alcanzando los 3000 ducados. El aumento del nivel de vida se refleja en el ajuar de la casa tasado en 480,5 ducados y los muebles en 75 ducados.

\section{Bienes muebles de Gregorio de Noboa Villamarín:}

- Productos agrícolas, cosecha: . . . . . 165 ducados y 9 reales

- Aperos, instrumentos agrícolas: . . . . 458,5 ducados

- Animales: ...............234 ducados

- Armas: .................26 ducados y 5 reales

- Ajuar de la casa . . . . . . . . . . 480,5 ducados

- Muebles .................75 ducados

- Dinero ...................500 ducados

- Papeles escrituras ............ 70 ducados

- Volumen linaje ............ 1000 ducados

TOTAL: .......... 3010 ducados y 3 reales

10 AHPOR, Memorial de bienes que dejó avinculados Francisca Vázquez de Puga. Bienes que "fincaron" de Gregorio de Noboa y su mujer, 1628 C9633, n¹74. 
Los productos e instrumentos agrícolas siguen ocupando un papel importante. Destaca el vino tanto en los productos agrícolas como en los aperos: 343 ducados es el valor de los objetos relacionados con faenas vinícolas (cubas, tinajas, piporros...); entre los aperos encontramos: un carro, sachos de cavar la huerta, utensilios para labrar madera, herramientas para "ferrar". La casa es autónoma en trabajos no específicamente agrícolas. Hay también tres "maseras" de dar comer a los cochinos.

Los animales son: 12 vacas, 2 bueyes, 40 cabras, 40 ovejas y carneros; un cuartago rocín ensillado y enfrenado de valor de 16 ducados y una mula también ensillada y enfrenada de 70 ducados.

Las armas, que suponen claramente una diferencia con respecto a los campesinos, se reducen a una escopeta, dos espadas, una ballesta y un venablo.

La partida que más ha aumentado en comparación con el inventario de Francisca Vázquez, es la referida al ajuar de la casa que se ha cuadriplicado (de120 a 480 ducados),

Encontramos objetos de hierro para colgar la leña en la chimenea, "gramallones" para colgar los calderos a la lumbre, un pote y algún otro objeto. Utensilios de cobre: dos cazuelas, dos cazos, un pote para traer agua, y también de estaño: media docena de "picheles de estaño que llevaran 18 nietos" y dos saleros de lo mismo.

Se citan algunos cubiertos para comer: "cuchillos de mesa y tenedores" y 4 cucharas de "frexio". Pero no aparecen objetos de loza de ningún tipo.

La ropa de casa es abundante: 3 docenas de sábanas, docena y media de mantas "de burel" y otra media de mantas rayadas, dieciocho colchones de lana, un docena de colchas, dos docenas de almohadas bordadas de seda negra, "colorada" y azul, que parecen ser las prendas más lujosas junto con un cobertor colorado de 8 ducados.

Una docena de manteles, 6 de "alamanisco" y 6 de otras labores, 3 docenas de servilletas y algunos paños.

La ropa de vestir se reduce a tres vestidos: uno de lanilla negro con su "ferrevel" negro, otro de pardillo fino con su capa de lo mismo y otro de paño de color de valor de 100 ducados. Y además media docena de camisas, "calzas" de lienzo y color, borceguís, botas de cordobán y otras prendas.

Por último, los muebles: tres camas de campo "con sus paños labrados de lienzo y de paño con sus flecaduras", dos lechos de palo, media docena de sillas de palo, una mesa, "un bufeite" con dos bancos, otros cuatro bancos más un "almario" con tres cajones y sus "pechaduras".

Y de casi tanto valor como los muebles, los papeles de las escrituras públicas y autos judiciales "de tal escribano propietario que fue de la Juris.on de la Peroja por espacio de tr.a años..." 
En el apartado del dinero se incluyen 300 ducados de deudas activas.

La tercera parte de valor de los bienes muebles la ocupa un volumen sobre los linajes "de este reino"; este enorme gasto debe estar en proporción al interés de Gregorio de Nóboa en demostrar o fabricar unos antepasados nobles. La importancia de la genealogía y la heráldica están en relación con la preocupación de la nobleza por mantener su status social y títulos de propiedad (J.Meyer, 1972).

En resumen, los bienes muebles de Gregorio de Nóvoa aunque se triplican con respecto a los de su madre, al igual que aumentan considerablemente sus rentas, no parecen poner de manifiesto un nivel de vida elevado similar al de un noble. No se cita ninguna joya ni objeto de cerámica valiosos. Su status nobiliario vendría dado por la posesión de un caballo mediano, una mula y algunas armas. No es mucho. Aparte de esto, eso sí cuantiosas rentas.

Curiosamente el único documento que atestigua este pasado ilustre de Gregorio de Nóvoa es la Información de Nobleza ${ }^{11}$ del año 1597, que se hace a partir de una querella presentada por el propio Gregorio de Nóvoa contra un criado suyo por haber dejado preñada a su sobrina. Afirma, junto con su hermano, padre de la moza, que

\begin{abstract}
"les convenía dar información como eran hijos naturales de Pedro de Bobeda y Noboa y de Francisca Vazquez de Puga, sus padres y de su nobleza y de cómo ellos y sus pasados eran y avian sido hijos dalgo notorios de solar conocido cristianos viejos limpios de toda raza porque si ahora no la hacian pereceria su justicia porque las personas que avian conocido a sus padres y abuelos (...) los que estaban en posesión de tales hijosdalgos y como se les avia guardado las franquezas y livertades de los tales sin jamas pechar en pechos de pecheros eran viejos y enfermos..."
\end{abstract}

Gregorio de Nóvoa pretende conseguir un status nobiliario. Sus antepasados no han pagado tributos y él tampoco tiene que hacerlo. La hidalguía aparece como "un grupo de titulados" cuya condición y título de nobleza a veces es claro y otras sólo consta el uso del "don" (Eiras Roel). Esto es lo que sucede en la casa de Fontefiz, Gregorio de Nóvoa es considerado el fundador del linaje, sin más base que la tradición y sus descendientes se titulan "don".

Entre las escasas notas que justifiquen este status estaría la llamada que se hace a D. Antonio de Puga en el año 1706 para que acuda a la defensa de la "raya de Portugal" junto con otros nobles. Se trata de la guerra de Sucesión, Felipe V es atacado en la frontera portuguesa por los aliados ingleses y holandeses. No sabemos si

${ }^{11}$ AHPOR, Información de nobleza de Gregorio de Nóvoa Villamarín, 1597 C9630, n 4 bis. Copia del año 1700 . 
D. Antonio acude. En 1762 hay otra llamada similar a D. Pedro de Puga y a su hijo, y este se excusa y manda su caballo por tener edad muy avanzada.

Así que, al lado de la tradición, unas vagas alusiones a la función militar de la nobleza. Estos son los argumentos esgrimidos a favor de la pertenencia a la categoría nobiliaria.

Si en teoría o desde un punto de vista formal se podrían poner pegas al acceso a este status social, en la práctica los miembros de este orden actúan como tales privilegiados, no ya por las prerrogativas que esto lleva consigo (exención fiscal entre otras), sino incluso por los abusos y señales de prepotencia de que hacen gala.

En un pleito particular que entabla D. Francisco Añel contra D. Rodrigo de Puga en 1725, éste es acusado de todo tipo de abusos y arbitrariedades, llegando a manipular la justicia, presentar testigos falsos y, si es necesario, llegar a tomar medidas de fuerza.

Según esta acusación, en el año 1701 "fue procesado criminalmente por la justicia (...) por los malos tratamientos que hizo al licenciado D. Santiago Rodríguez”. En 1724, por lo mismo, a otro escribano, Pedro Tomás de Nóvoa.

Sus abusos afectan muy directamente a los campesinos pagadores de renta:

"siendo igualmente cierto que debiendo cobrar diferentes rentas de vino usa pa. recivirlas de medidas excesivas poniendo de treinta y dos quartillos los que debe tener solo veinte y seis (...) y com es persona poderosa les hace condescender en ello (...)y porque la justicia por lo regular hes nombrada a su contenpla.on y aun muy de ordinario lo es uno de sus caseros (...) siguiéndose de esto el no atreverse aquella justicia a procesarle sobre los referidos delitos" 12

Domínguez Ortiz se refiere a los abusos en el campo de la justicia que tienen lugar en la España del siglo XVIII, ya que bajo los Borbones casi el único resto que le quedó a los señores de su antigua potestad jurisdiccional fue la justicia municipal, en la que en un grado u otro, pero siempre de manera efectiva intervenían, y los abusos eran frecuentes. También Rodríguez Ferreiro testimonia la complicidad entre la hidalguía y las personas que ocupan cargos de justicia.

Los abusos de este grupo dominante se extienden al ámbito sexual. En este campo la primacía del varón es indiscutible siempre que pertenezca a los priviligiados.

En la Información de nobleza de Gregorio de Nóvoa, a fines del siglo XVI, vemos como Juan Gil, criado de este, es acusado de haber dejado preñada a la sobrina de su amo y por ello es encarcelado y condenado a galeras por doce años, más otros seis de destierro además de pagar las costas del proceso. La condena

12 AHPOR Pleito particular de D. Francisco Añel y Puga, vecino del lugar de Villar de abajo, feligresía de Santa María de Ucelle, Coto de la Real Encomienda de la Barra, 1725, C9635, n²41. 
parece apoyarse más en las diferencias sociales de los implicados, una hidalga y un criado, que en el "delito" en sí.

Es ilustrativo el proceso por estupro que se hace en 1676 a D. Antonio de Puga:

"el dia veinte y nueve de abril passado deste año avia forccado y estrupado a dcha Isabel Sánchez en la eredad que se dice da Caveira".

D. Antonio, al enterarse de que la susodicha moza junto con su madre y su cuñado se encaminan a la Audiencia para dar cuenta al fiscal y acusarlo a él, pone en marcha sus contactos y por medio del escribano de la Peroja, Domingo Vázquez Domato, intente evitar que el tal fiscal no haga la acusación.

Y, sin pérdida de tiempo, al día siguiente, emprende, con este mismo escribano, una querella criminal contra los tres denunciantes

"por decir que siendo como era p(erso)na noble y principal apartado de todo mal vicio y costumbre (...) habia forzado a esta moza"

En virtud de esta querella se ordena encarcelar a los antes citados y embargar sus bienes. Así Isabel Sánchez "fue pressa en la Jurisdicción de Melias" aunque a los otros dos "culpables" no se les pudo detener y se les embargaron los bienes.

Esta reacción (el acusado se convierte en acusador y los que acusaban a D. Antonio terminan en la cárcel), no debía ser inusual. Rodríguez Ferreiro cita casos similares en los que si una mujer no noble (pechera) que queda encinta de un hidalgo y denuncia su estado, inculpándolo para que éste se haga responsable, podía acabar en la cárcel. ${ }^{13}$

Queda claro en este caso la actitud de este hidalgo que resalta su carácter de privilegiado: "persona noble y principal" ante la acusación que se le hace.

D. Rodrigo de Puga representa con claridad este comportamiento abusivo en el plano sexual, doblemente, como varón y como privilegiado. En el año 1714 fue procesado criminalmente por

"estar amancebado siendo hombre casado con Ana Frz. Sotelo soltera"

Posteriormente tuvo

"Ylicita correspondencia de una hija de Bar(tolo)me de Montes soltera(...) aviendo procreado de ella un hijo, teniendo actualmente ylicita correspondencia con cierta muger casada”.

${ }^{13}$ Rodríguez Ferreiro, H., La hidalguía rural del Morrazo en el S. XVIII: analisis sociológico de un grupo dominante, pág. 241. 
En el caso de encontrar obstáculo D. Rodrigo no duda en recurrir a la fuerza:

"aviendo al mismo tiempo solicitado a otras maltratándolas e hiriéndolas por averse resistido". ${ }^{14}$

Estas actitudes de abuso y prepotencia, que no parecen ser casos aislados, ponen de manifiesto el poder de la hidalguía en la sociedad gallega del Antiguo Régimen, basada en la desigualdad social y jurídica. También ponen de manifiesto el poder de los hombres, especialmente los nobles, en una sociedad patriarcal.

Sobre la violencia contra las mujeres tenemos un testimonio literario del siglo XIX en la obra "Los pazos de Ulloa" de Emilia Pardo Bazán.

La posición de los titulares de esta casa dentro del estamento nobiliario parece ser media baja, por lo menos esto es lo que podemos deducir del análisis de las "mandas" en los testamentos. El número de misas no es muy elevado si tomamos como referencia los datos de Barreiro Mallón (la media de misas encargadas en los testamentos es de 450 para la nobleza y 50 para el campesinado, aunque aclara que determinados pequeños nobles tienen una media mucho más baja de misas $)^{15}$.

Los testamentos que conocemos indican para la casa de Fontefiz un máximo de 100 misas.

Francisca Vázquez (testamento de 1611), que pide ser enterrada en San Ginés, deja encargadas 50 misas de las cuales una ha de celebrarse en Ourense en el "Santo Crucifijo" o en la capilla de San Luis en San Francisco. Hace además una fundación de seis misas perpetuas el día de San Gregorio en la iglesia de San Ginés.

Gregorio de Nóvoa, también es enterrado en San Ginés "en la capilla mayor en la sepultura en donde yace mi padre e Ygnes Diaz de Cadorniga mi segunda muger la cual tengo dotada". Encarga cien misas, el doble que su madre.

Y D. Antonio de Puga, que hace testamento en 1709, casi un siglo después del de Gregorio de Nóvoa, mantiene las mismas cien misas; es enterrado en la iglesia de Ucelle "en sepultura señalada y dotada". Precisamente esta sepultura será motivo de pleitos para sus sucesores.

Hay pues una clara relación entre el status social y las misas que se encargan. Por otra parte, la minuciosidad con la que se establecen estas cuestiones pone de manifiesto el poder de la Iglesia en la mentalidad de esta época.

\footnotetext{
${ }^{14}$ AHPOR, Pleito particular de 1725. Cargos presentados por D. Francisco Añel contra D. Rodrigo.

${ }^{15}$ Barreiro Mallón, B.: Las clases urbanas in Santiago en el S. XVII: definición de un estilo de vida y pensamiento. 1980 .
} 
Los enfrentamientos con otros hidalgos aparecen a lo largo del siglo XVIII debidos a cuestiones de prestigio y preeminencia social o referentes a desacuerdos en prorrateos. ${ }^{16}$

En 1708 D. Antonio coloca una lápida cerca del altar mayor de Ucelle después de haber adquirido allí una sepultura. Otro hidalgo de la misma feligresía, D. Francisco Añel y Soto se opone a este derecho y entabla pleito contra su hijo y sucesor, D. Rodrigo de Puga. Éste gana el pleito en 1725 "sobre el derecho que tenía de poner un banco en una sepultura suya". Pero el asunto no concluye aquí porque en un segundo pleito en 1729 el prior de San Marcos de León le da la razón a D. Francisco Añel y la escritura de adquisición de la sepultura es anulada y se ordena retirar la lápida.

Otros conflictos están motivados por razones estrictamente económicas como la "querella de fuerza" que lleva a cabo la casa de Bamio contra D. Rodrigo en 1733 por un memorial de bienes.

También es D. Rodrigo quien hace una relación de los "perjuicios y agravios"que le han hecho el Marqués de Bóveda y otros en 1726.

Conflictos relacionados con el desacuerdo en el reparto de renta en los prorrateos: querella dada por D. Pedro de Puga contra D. Francisco Feijoo de la casa de Bamio en 1775.

Y, a finales del siglo XVIII, otro conflicto relacionado con el control del aparato judicial: en 1797 es elegido juez de la Barra D. Francisco Feijoo y esto provoca al parecer el desacuerdo de D. Ramiro de Puga.

Un ejemplo de las precauciones a tomar en caso de conflicto con otras casas hidalgas es la aparición, entre los documentos de Fontefiz, de una referencia al "Inventario de la casa de Lagariños" con la indicación: "puede ser util a la Casa de Fontefiz el verlo"17.

Estos enfrentamientos internos de la hidalguía ponen de manifiesto los problemas con los que va a encontrarse a fines del Antiguo Régimen, problemas que se agudizan en el siglo XIX al cuestionarse el propio papel de la hidalguía.

Los hidalgos de la Casa de Fontefiz comparten su situación de privilegio con otros nobles en el Coto de La Barra. Según el "testimonio del empadronamiento del Real Coto de la Barra", que en el año 1801 solicita D. José Ramiro de Puga del escribano Juan Clemente de Temes (este documento será utilizado más tarde por su hijo, Pedro Ventura de Puga, cuando se ponga en duda su nobleza), en el

16 Villares, R. cita ejemplos de enfrentamientos internos de la hidalguía en el S. XVIII. La propiedad de la tierra en Galicia, pág.127-128 y nota 271.

${ }^{17}$ AHPOR, C9633, nº140. 
citado Coto hay diez nobles para un total de 102 vecinos. Los más destacados son:
D. Francisco Feijoo y Ron de la Casa del Bamio
D. Manuel Rodríguez Feijoo de la casa de Tras do Pazo
D. José Ramiro de Puga de la Casa de Fontefiz

\section{LAS DIFICULTADES DEL SIGLO XIX}

El siglo XIX supone para España la continuidad con el Antiguo Régimen durante, por lo menos, el primer tercio. En Galicia esta situación se prolonga hasta el siglo XX con la persistencia del régimen foral ${ }^{18}$. La hidalguía, principal defensora y beneficiaria de este sistema basado en la apropiación de la renta, se va a resentir de los cambios que trae consigo la aparición de una sociedad liberal ${ }^{19}$. Este sistema económico, del que la Casa de Fontefiz es un ejemplo, intenta mantenerse y sufre un deterioro al ser marginado por las nuevas condiciones de la sociedad liberal, porque lo que está claro es que la renta no puede aumentar (por el propio carácter del contrato), pero los gastos sí aumentan por los impuestos y por las dificultades, cada vez mayores, para cobrar las rentas.

¿Cuál es la situación económica de la casa en el siglo XIX?

La Casa de Fontefiz, de la que Pedro Ventura es el último señor, surge en San Ginés de la Peroja a partir de un núcleo inicial anterior al último tercio del siglo XVI, aumenta de un modo espectacular su patrimonio, basado mayoritariamente en la percepción de rentas, en los años finales del siglo XVI y principios del XVII. Su patrimonio se redondea con numerosas compras de tierra a finales del siglo XVII y, especialmente del XVIII, lo que contribuye a redondear este patrimonio.

Pedro Ventura de Puga, se convierte en un rentista con importantes ingresos poco después de su matrimonio, cuando, al morir su padre en 1805, toma posesión de los bienes de Fontefiz y Nande.

El patrimonio de Fontefiz, a principios del siglo XIX, supone alrededor de los dos mil ferrados de centeno y casi dos mil cuartas de vino, cifras que lo sitúan en un lugar destacado entre la hidalguía gallega.

\footnotetext{
${ }^{18}$ Sobre la vigencia del régimen foral ver R. Villares: La propiedad de la tierra..., pág. 147 y ss.

La Casa de Fontefiz realiza aún en 1906 un prorrateo de dos forales en el que mantiene la renta de centeno y rebaja a casi la mitad la de vino.

${ }^{19}$ Sus dificultades, como afirma R. Villares, radican más "na súa incapacidade pra se transformar internamente e pasar de ser clase intermediaria a ser burguesía agraria capitalista" que en la disminución de sus ingresos que se mantienen prácticamente estables. Foros, frades e hidalgos, pág. 127.
} 
Rentas percibidas por la Casa de Fontefiz a principios del S. XIX ${ }^{20}$ :

\begin{tabular}{|c|c|}
\hline Centeno: . . & (ferrados) \\
\hline Trigo: & (ferrados) \\
\hline Castañas: ....... 68 & (ferrados) \\
\hline Maiz: ........ 133 & (ferrados) \\
\hline Vino: . . . . . . 1.958 & (cuartas) \\
\hline
\end{tabular}

A lo largo de este siglo la coyuntura negativa para los precios agrícolas provoca dificultades económicas para la Casa: aunque se mantiene la cuantía de las rentas, hay graves problemas para cobrar las mismas por lo que se hace necesario acudir a los prorrateos (que suponen el 63\% del vino y del trigo que recibe Fontefiz, y el 35\% del centeno).Los prorrateos ponen de manifiesto la dificultad que este hidalgo tiene para cobrar sus rentas: "en el día se hace tan penosa la cobranza que sobrepasa la molestia a la utilidad". Quizá debido a estas dificultades, las redenciones se inician muy pronto: en 1821, Pedro Ventura paga 16 vales nacionales para redimir rentas forales. En 1823,1840 y 1841 vuelve a redimir más rentas y, por último, en 1855 y 1856 redime 21 foros a diversas entidades eclesiásticas. Hasta mediados del siglo XIX las redenciones suponen importantes cantidades que suman la cifra de 130.000 reales. La legislación liberal, por medio de las redenciones, permite a la hidalguía deshacerse de la carga que supone el pago de renta pasiva a entidades eclesiásticas. Así que la legislación del régimen liberal no sólo no perjudica, sino que favorece a la economía de este hidalgo. Las primeras leyes desamortizadoras, ya durante el Trienio constitucional, son aprovechadas por Pedro Ventura para desembarazarse del lastre que supone el pago a entidades eclesiásticas (monasterio de San Clodio, priorato de Rozamonde, dependiente del monasterio de San Martín de Santiago, monasterio de San Salvados de Celanova y la Encomienda de la Barra) y redimir rentas forales.

Las dificultades económicas de la hidalguía gallega debido al descenso de los precios agrícolas ${ }^{21}$, y concretamente de Pedro Ventura de Puga se ponen también de manifiesto en los memoriales de deudores.

${ }^{20}$ La cuantía del patrimonio es provisional. Aparecen nuevos datos referidos al siglo XX, lo que pone de manifiesto la fragmentación y heterogeneidad de las fuentes manejadas. Otras Casas hidalgas presentan las siguientes rentas: Casa-Torre del Monte (Padrón): 1.567 ferrados de centeno; Pazo de Oca: 1.250 ferrados de centeno; Casa de Roda: 1.500 ferrados de centeno; Casa de Lusío (Samos): 840 ferrados de centeno; Casa de Lagariños (sólo el partido de Lagariños): 1.320 ferrados de centeno. Datos tomados de R. Villares, La propiedad de la tierra..., pág. 50-51 y Anexo, pág. 71-72.

${ }^{21}$ El primer tercio del siglo XIX coincide con una fase depresiva que se prolonga hasta 1843 en la que descienden de un modo acusado los precios agrícolas especialmente en los años 1817-1819. Fontana, J. : La quiebra de la monarquía absoluta 1820, pág. 45-46. 
Reproduzco a continuación una relación de precios de centeno en el "partido" de La Peroja y Amoeiro ${ }^{22}$ que ilustra este descenso:

Precio del ferrado de centeno desde 1802 a 1821:

$\begin{array}{lll}\text { 1802: } 13 \text { reales } & 1809: 19 \text { reales } & 1816: 13 \\ \text { 1803: } 16 \text { reales } & 1810: 22 & 1817: 19 \\ \text { 1804: } 11 \text { reales } & 1811: 23 & 1818.8 \\ \text { 1805: } 10 \text { reales } & 1812.14 & 1819.5 \\ \text { 1806: } 13 \text { reales } & 1813: 13 & 1820: 3,5 \\ \text { 1807: } 11 \text { reales } & 1814: 13 & 1821: 4 \\ 1808: 8 \text { reales } & 1815: 12 & \end{array}$

A principios del XIX hay 73 "llevadores que adeudan a la Casa de Fontefiz 508 ferrados de centeno". En 1808 vuelve a solicitar otra Provisión de deudores en la que aparecen cincuenta deudores. Las dificultades de la casa llevan a presionar sobre el campesinado y, en caso de impago, se llega al embargo.

Además, el nivel de gastos es elevado para la hidalguía: Precisamente en este momento los gastos aumentan porque el status social de los titulares de Fontefiz es cuestionado por los vecinos del Coto de la Barra y ello obliga a Pedro Ventura a realizar numerosas consultas a Valladolid, A Coruña y Ourense, "sobre conseguir carta de posesión y propiedad de la nobleza" lo que le ocasiona los consiguientes gastos. Es interesante escuchar su opinión y quejas:

“Los vecinos de este Real Coto en la diligencia de aprovación de padrón de 1827 (acordaron) negarme mi nobleza hereditaria (...) guiados por su espíritu nivelador (...) hechan por tierra las clases y mandan que se presenten los agraviados, si es que llegase a haver alguno los documentos que tengan (...) un proceder tan contrario a ntras. Leyes y a las costumbres (...) indica bien el espíritu que los animo en este acto y la malicia que tuvieron pa. hacerme gastar en seguimiento de un expediente..." 23

En lo que se refiere a la naturaleza del patrimonio de Fontefiz, queda claro el predominio de las rentas, pero en el siglo XIX nos encontramos con el régimen de aparcería que juega un importante papel en el conjunto de su economía. La Casa de

\footnotetext{
${ }^{22}$ Razón de precios dada en el año 1822 por el Conde de Rivadavia a petición de Pedro Ventura de Puga con motivo del cobro de los atrasos del foral de Quintas de Boimorto. AHPOR C $9631 \mathrm{n}^{\circ} 50$.

${ }^{23}$ Petición hecha por D. Pedro Ventura...señor de la casa solar de Fuentefiz en el Coto de la Barra probando que sus ascendientes por línea de barón residieron en dicho Coto y gozaron desde tiempo inmemorial la preeminencia y distintivo de nobles de sangre y notorios hijosdalgo. Alegatos presentados para obtener la ejecutoria. AHPOR C9639 nº391. Consultas que se han hecho a Valladolid...C9632 nº5.
} 
Fontefiz recibe diversos ingresos que se han ido incorporando a su patrimonio a través de dotes. Este es el caso de la Casa de Nande (Carballedo, Lugo), que pertenece a Fontefiz desde el último tercio del siglo XVI, por dote de Inés Díaz de Cadórniga. Y también la Casa de Argeriz (Saviñao, Lugo), incorporada a Fontefiz, a mediados del siglo XVIII, a partir de la dote de la abuela paterna de Pedro Ventura, Constanza Rajó y Suárez.

El predominio aplastante que las rentas ejercen sobre la economía de las casas hidalgas, ya que el hidalgo es ante todo un rentista, ha hecho que no se valoraran otras fuentes de ingresos. Pero, en el caso de Fontefiz, el régimen de aparcería juega un papel importante: Argeriz aporta el 13\% del total del centeno que recibe la casa y el $25 \%$ del trigo.

El régimen de aparcería implica un control más directo: se especifican normas para la explotación del ganado, los cultivos que se han de hacer, cómo efectuar la siega, dónde vender...Además, el contrato no estipula la duración del mismo sino que este importante aspecto, se deja al arbitrio del propietario.

El primer contrato de aparcería que tenemos de Nande, lo firma Pedro Ventura en el año 1806:

"Se da el lugar de Nande a Juan Regal y Tomás Rodríguez. "con sus casas corrales tierras de labradio, tojales, montes y prados según se demarca en coto redondo con las condiciones siguientes: qe mediante no se coje otro fruto ms qe centeno solo de este se ara la partija pr metad sacando antes de acerla del montón de cada uno catorce fanegas y un ferrado pr razon de semiente, renta, manutención de jornaleros y personas qe dicho Dn. Pedro dispute pa. presenciar maja y siega y ms. necesario pa beneficiar los frutos qe a el le toquen. Qe si el Dn. Pedro quisiere conducir a su casa de habitación dichos frutos an de estar prontos con carro y ganado pa ayudar a su conducion como a cualquiera otro carreto qe necesite. Qe para hacer las labores de siega y maja an de abisar dos dias antes de principiarlas y lo mesmo cuando quieran bender algun ganado en la feria de Orban a donde solo se beneficiara todo y se conprara tanbien el que aga falta pr qe como este a de ser a medias necesita el Dn. Pedro buscar persona de su satisfacción qe presencie estas bentas y compras. Qe cuando aiga de morir alguna res deenfermedad an de hacer constar la certeza de este u otro accicende (sic) con testigos oculares fidedignos o pr otro modo pr donde se coliga la evidencia de esta desgracia”.

En 1816 se vuelve a redactar otro contrato, por defunción del anterior casero, y en el se estipula que la duración del contrato será a voluntad “del Dn. Pedro (...) de suerte qe pr el tiempo que yo quisiera estaran y cultivaran el lugar y nada mas" 24 .

${ }^{24}$ AHPOR C9634 nº194, 186. 
¿Cómo es la vida de Pedro Ventura y de su familia? La documentación existente sólo nos permite conocer datos de la actividad política del varón de la casa y de su situación económica. No hay casi referencias a su mujer, María Antonia de Puga de la casa de Santa Mariña de Augas Santas, ni a sus dos hijas, una de las cuales debió de morir joven porque casi no hay datos sobre ella; la otra, María Manuela de Puga se casa con el marqués de Leis, José María Montenegro Gago Pimentel y España, que reside en Ourense.

Los datos de la explotación directa de la propia Casa de Fontefiz de los años 1824 y 1825, nos permiten ver como, aparte de que los ingresos son poco importantes y, a duras penas, llegan para sostener los gastos de la casa, son controlados por Pedro Ventura y el capellán Pedro Antonio Díaz, que es también administrador. María Antonia de Puga, su mujer, aparece en la partida de gastos (entre el pago a los criados, zapatero, compra de productos alimenticios, como jabón, aceite y arroz, etc):

En 1824, gastos sin especificar hechos "por la Sra. de 200 reales". Y, en 1825, se le entregan a la "Sra. 496 reales".

De aquí se pueden extraer dos conclusiones: Que los ingresos de la explotación directa no son suficientes para mantener el nivel de vida de la casa y que sin las rentas no sería posible este nivel de vida.

Y que la economía familiar es también controlada por el titular de la casa, sin que su mujer parezca tener ninguna intervención.

\section{PEDRO VENTURA DE PUGA, ÚLTIMO SEÑOR DE FONTEFIZ}

¿Quién es Pedro Ventura de Puga?

El último señor de Fontefiz nace, en 1775 y muere, con 91 años, en 1866.

Vive una larga vida entre el último tercio del siglo XVIII y la primera mitad del siglo XIX: el fin del Antiguo Régimen con Fernando VII, la instauración de un régimen liberal con Isabel II, cambios políticos y pervivencias sociales y económicas.

Ilustrado reformista, como veremos en sus escritos, y liberal moderado, en su actividad política. Recorre los escenarios gallegos de la guerra de Independencia y viaja a Londres en misión oficial. Es, a la vez, un hombre ligado al campo que pasa la mayor parte de su vida en el pazo de Fontefiz.

Estudia en Ourense y después en Santiago de Compostela "donde tuvo por maestros a los hombres de más ilustración y cultura de su época" Fue calificado de "nemine discrepante" en toda la carrera de Derecho y después se hizo doctor en Salamanca. (Fernández Alonso). 
Su formación es propia del siglo XVIII como él mismo reconoce:

"hice mis estudios en el siglo 18 y devo resentirme un tanto de las doctrinas que estaban en boga en aquel tiempo".

Forma parte de la Sociedad Económica de Amigos del País de Santiago.

Es un hombre de su época y participa activamente en la vida política. Sabe adaptarse a los nuevos tiempos que el régimen liberal trae consigo e incluso alaba la Constitución:

\section{"La Constitución abolía justamente los privilegios y nos hizo a todos iguales ante la ley" 25}

Sin embargo, esta actitud no es para él incompatible con el mantenimiento de las bases de su propia economía y la defensa de los foros o los títulos de nobleza.

Pedro Ventura de Puga personifica la contradicción entre una sociedad de base agraria y tradicional y la nueva estructura política del Estado Liberal español.

Como veremos, esta contradicción es sólo aparente puesto que el régimen liberal no perjudica los intereses de la hidalguía ya que el sistema foral continúa vigente durante todo el siglo XIX y llega hasta el primer tercio del siglo XX. La legislación liberal sanciona la "congelación" del sistema foral de la Provisión de 1763, confirmada por otras leyes de fines del Antiguo Régimen.

La hipótesis sería la siguiente: si el régimen liberal no perjudica los intereses de la hidalguía gallega ¿por qué no apoyarlo?

Pedro Ventura de Puga no parece ser un absolutista trasnochado, como afirma Barreiro Fernández, sino que se incorpora al liberalismo dentro de su sector moderado. Esto es lo que hemos deducido de sus escritos y de su actividad política. ${ }^{26}$

Esta actividad se inicia en la Guerra de Independencia donde su participación es destacada como miembro de la Junta Superior. La Guerra de Independencia supone en Galicia la continuidad de las clases dirigentes en los órganos de poder

\footnotetext{
${ }^{25}$ AHPOR C9706, 15 mayo 1842. Borrador de Pedro V. de Puga en el que hace una exposición de méritos para lograr que su yerno consiga el título de Marqués de Leis. Es una defensa de la Constitución no exenta de interés, pero hay que resaltar que la constitución vigente en estos momentos es la de 1837 , de carácter progresista.

${ }^{26}$ Barreiro Fernández afirma que D. Pedro es "ultraconservador" dentro de la variedad de opciones políticas de los diputados que se presentan a las elecciones de 1834. "Desde los ultraconservadores como D. Pedro Ventura de Puga, al que sin duda debió de costarle presentarse a diputado rompiendo con los carlistas, con los que estaba su corazón”. Historia Contemporánea de Galicia, T.II, pág. 39, 1982.
} 
(Díaz Otero, 1981). De esta época no conocemos aún su postura política pero sus escritos no revelan el estilo agresivo que los absolutistas utilizan para referirse a los franceses ${ }^{27}$.

A la vuelta de Fernando VII, en 1814, lo encontramos formando parte de la Sociedad Económica de Amigos del País de Santiago. Participó en la vida municipal de Ourense como regidor. En el Trienio Liberal figura como miembro de la Diputación de Galicia y de Ourense. De la última etapa del reinado de Fernando VII no conocemos sus actividades públicas pero sí al instaurarse el régimen liberal cuando es nombrado procurador en Cortes.

No tenemos ningún escrito en el que Pedro Ventura exprese sus opiniones políticas (a excepción de las que se pueden deducir del escrito: "Origen y facultades de la Junta del Reino de Galicia"; la mayoría de sus textos se refieren a cuestiones de tipo económico y, aunque sus planteamientos sean anticuados, no parece que esto lo sitúe en el campo del absolutismo.

Pero sí conocemos su práctica, su actividad política y su faceta ilustrada que lo sitúan en una línea del liberalismo moderado.

Su partida de bautismo nos aporta datos concretos:

Nace el 9 de Marzo de $1775^{28}$ en Bobadela (Celanova), tierra de su madre, y es bautizado en la iglesia de Santiago de Pardavedra por D. Bernardo de Guitián y Arias, abad de Sta. Leocadia de Soutomel.

Son sus padres "personas adineradas" (Fernández Alonso, 1916): D. José Ramiro de Puga Suárez Deza y Villamarín, natural de la Casa de Fontefiz, y Doña. Ma Manuela Gómez Suárez de Alvarín, de la Casa de Entrambosríos y Pardavedra. Como padrinos aparecen D. Antonio Gómez Araujo, presbítero y vecino de la parroquia de Sta. $\mathrm{M}^{\mathrm{a}}$ de Entrambosríos y Dña. Manuela Gómez, su hermana.

Viven en este momento su abuelo paterno, D. Pedro Ventura de Puga, dueño de la Casa de Fontefiz, de quien hereda el nombre y su abuelo materno, D. Francisco Gómez Araujo. Han fallecido ya sus abuelas maternas, Doña. Constanza Rajó y Suárez, dueña que ha sido de la Casa de Argeriz en el valle de Lemos, y Doña. M $^{\mathrm{a}}$ Antonia Suárez.

Es, por tanto, heredero de un importante patrimonio por ambas partes.

Su hermana Doña $\mathrm{M}^{\mathrm{a}}$ Antonia se casa en 1798 con D. Tomás Domínguez.

${ }^{27}$ Barreiro Fernández: Liberales y absolutistas en Galicia, Vigo, 1982 (pág. 105 y ss). El mismo autor señala que "los reaccionarios apenas exponen teorías económicas en sus escritos"(pág. 128).

${ }^{28}$ Según su partida de bautismo. AHPOR, Cas. Part. C9706. Benito Fernández Alonso da dos fechas erróneas, 1772 y 1773, Orensanos ilustres, pág.125. 1916. También se equivoca en el nombre de la madre de Pedro V. e indica que se llama $\mathrm{M}^{\mathrm{a}}$ Antonia. 
Pedro Ventura se casa a los 26 años, en 1801, con Mª Antonia de Puga, "menor de 25 años", de la Casa de Santa Mariña de Augas Santas ${ }^{29}$.

Sus padres, al ser el primogénito, lo mejoran en el tercio y quinto de todos sus bienes además de su legítima. Recibe los siguientes bienes:

- El lugar y la casa de Argeriz con todos sus bienes y rentas libres.

- Las casas que hay en Monforte y en su valle con sus rentas, muebles y ganado.

- Los moios de vino que se perciben de renta en la feligresía de Rivela.

- 39 ducados anuales percibidos en tierra de S. Andrés de Coontán.

- Todos los bienes raíces dros. efectos y acciones del lugar de Albarín.

Además, su mujer $\mathrm{M}^{\mathrm{a}}$ Antonia recibirá de su padre, José Ramiro de Puga, 1500 r.v. en dinero para su bolsillo cada 15 de agosto mientras viva. También, cada año, 1000 ducados "que capituló pagaría a su hija hasta veinte años".

$\mathrm{Y}$ en abril de 1805, toma posesión de los bienes de Fontefiz y Nande, al haber muerto su padre en junio del año anterior.

Su situación económica es la de un rentista con importantes ingresos.

Tiene dos hijas de su matrimonio, aunque una de ellas debió de morir pronto porque casi no hay referencias de ella. La otra es $\mathrm{M}^{\mathrm{a}}$ Manuela, que se casará con José $\mathrm{M}^{\mathrm{a}}$ Montenegro Gago Pimentel y España, Marqués de Leis y Vizconde del Buen Pazo, que reside en Ourense.

D. Pedro pasa la mayor parte de su vida en el pazo de Fontefiz, dedicado a "mis negocios domésticos única causa de mi vida", salvo breves intervalos en los que tiene que ausentarse debido a su constante actividad pública: años 1810 y 1811 durante la guerra de independencia, en 1835, procurador en Cortes por Ourense...

Los últimos años de su vida los pasa en la ciudad de Ourense (empiezan a abandonarse los pazos), probablemente en la calle Arcedianos.

El 10 de junio de 1866 muere en esta ciudad y sus restos, bajo una lápida con inscripción, se hallan en el cementerio de San Francisco ${ }^{30}$.

Como corresponde a su condición social, D. Pedro participa activamente en la vida política y, como corresponde a su condición social, defiende las estructuras sociales y económicas del antiguo régimen: los foros, las pruebas de hidalguía...

${ }^{29}$ Escritura de capitulación, 26 de julio de 1800. AHPOR Cas. Part.C9632 nº161. En la obra "Blasones y linajes de Galicia" de P. Crespo del Pozo, aparece Pedro V. casado con Doña Constanza Suárez de Deza, quien en realidad es su abuela. Probablemente la confusión radica en que Pedro V. se llama igual que su abuelo paterno. Vol IV, pág. 258.

${ }^{30}$ Emilio González López (Galicia bajo el reinado de Isabel II), aparte de confundir el nombre de Pedro Ventura de Puga (indistintamente le llama así o Pedro de la Vega), sitúa su muerte en Madrid en vez de en Ourense. 
En junio de 1808 forma parte de la Junta de Ourense. Es Regidor perpetuo del mismo ayuntamiento desde, por lo menos, 1815. Durante la guerra de Independencia tuvo una destacada intervención: en julio de 1808, representante del estado nobiliario por Ourense en el Congreso Nacional de A Coruña; en diciembre de 1809, es elegido por el estado general de Ourense par ser su representante en la Junta Superior de Armamento, Subsidios y Defensa. Como vocal de la Junta viajará a Londres en 1810, y a finales de este año, a Puebla de Sanabria. Elegido diputado a Cortes, como suplente, en representación de la misma Junta, en julio de 1810; secretario de la J. S. a partir de diciembre de 1810.

Miembro del ayuntamiento de Ourense, como Regidor.

Diputado por la provincia de Ourense durante el Trienio Constitucional, aunque luego, en 1824, ante la represión de la Década Ominosa, certifique que "ignoraba haber sido nombrado individuo de la Diputación".

Miembro de la Sociedad Económica de Amigos del País de Santiago según consta en un recibo del año 1814.

Colaborador de la Real Junta de Comercio de la Coruña, ante la cual presenta un informe en 1832 sobre el estado de la agricultura, artes, industria, comercio y navegación de Galicia.

Comisionado por el ayuntamiento de Ourense para felicitar a Fernando VII en 1833 por su mejoría junto con el Marqués de Villaverde. El viaje no se realiza por enfermedad de Pedro Ventura de Puga.

Comisario de millones en enero de 1814; diputado del Reino en el mismo año, en el que precisamente se disuelve.

Procurador en Cortes en 1835, pertenece a la Comisión encargada de informar sobre el proyecto de ley acerca de la enajenación forzosa por motivos de utilidad pública.

Forma parte de la Comisión consultiva para el fomento y mejora de la cría caballar de la provincia de Ourense. Participa también en la Junta de agricultura que se crea a partir de las anteriores comisiones. En 1851 presenta, a esta junta, un informe sobre la propagación de la cría de la seda en Ourense y su provincia.

En 1849 es nombrado Comisionado regio en la provincia de Ourense para la inspección de la agricultura.

Y, aún en el año 1854, con 79 años, es nombrado vocal de la Comisión encargada de organizar la asistencia a la Exposición de París.

Son, por tanto, numerosas sus actividades, especialmente las centradas en cuestiones agrícolas. 


\section{ACTIVIDADES POLÍTICAS: LA GUERRA DE INDEPENDENCIA}

En esta época encontramos abundantes datos sobre las actividades de Pedro Ventura. Sin embargo, la bibliografía existente sobre la misma se centra básicamente en los hechos bélicos, bien con una visión de conjunto sobre Galicia (Portela Pazos) o parcial de diferentes zonas o personalidades (Vázquez Martínez), en todo caso se detienen en el año 1809 con el fin de la invasión. Únicamente las obras de Díaz Otero y Martínez Morás analizan aspectos institucionales y políticos a través de la evolución de la Junta Superior del Reino de Galicia. Y una interpretación global del proceso, desde el punto de vista político, la encontramos en Barreiro Fernández.

En todo caso la falta de un estudio monográfico sobre la guerra de Independencia en Ourense, nos obliga a detenernos en este episodio para poder valorar la actividad de D. Pedro quien cuenta con treinta y tres años. Participa activamente desde 1808 hasta 1812 .

\section{- La guerra de Independencia}

En Galicia el levantamiento contra los franceses se produjo en primer lugar en la ciudad de A Coruña. El 30 de mayo se origina un levantamiento popular frente al palacio de Capitanía que trajo consigo la formación de una Junta General Provisional y una Junta Permanente para resolver los problemas de trámite, lo que culminó en la creación de la Junta Superior del Reino de Galicia que asumió un carácter soberano ${ }^{31}$.

En la composición de estos organismos hay un predominio de autoridades del Antiguo Régimen: al menos 30 de los 46 miembros de la Junta General, tenían puestos de mando ligados a la anterior administración. Por lo tanto no va a existir ruptura en los equipos dirigentes de antes y después del levantamiento ${ }^{32}$

Esto, en general, es lo que va a suceder en toda Galicia, con la diferencia de que si la Junta de la Coruña surgió a partir de un levantamiento popular, en el resto de las ciudades los alzamientos son más controlados por los grupos dirigentes que son los que están al tanto de lo que sucede en A Coruña y Santiago.

En Ourense, aún el 17 de mayo se divulga una pastoral de su obispo D. Pedro Quevedo, en la que dice que debe practicarse la caridad con los soldados franceses ya que son "huéspedes y se precisan de amigos nuestros” y se califica a Napoleón

${ }^{31}$ La Junta determina declararse suprema y gubernativa del Reino de Galicia a nombre de S.M. Fernando VII. La ruptura con el gobierno central está legitimada por hacerse en nombre del rey y por el apoyo del levantamiento popular.

32 Díaz Otero, Orígenes, estructura y evolución de la Junta Suprema de Galicia. 1808-1816, pág. 23. 
de emperador grande, justo y católico y "poderoso aliado, amigo y protector", para terminar indicando "no deis oidos a vanos rumores", con una clara referencia a la inquietud del momento. (Fernández Alonso 1908).

Sin embargo, el 1 de junio al recibirse las noticias de Santiago (donde se ha formado una Junta integrada por gentes próximas al arzobispo), se moviliza la población y se constituye una Junta. De los disturbios que se originaron nos habla el siguiente documento:

..." a las ocho treinta de esta noche en que llegó el Posta qe. Conducía el pliego de V.S., empezó otro movimiento en ella de bastante consideración dirigido a que el Correxidor entregase las órdenes que tenía el Serenísimo Señor Gran Duque de Berg para quemarlas levantando varias Banderas en palos publicando viva Fernando $7^{\circ}$, de modo que pa. Evitar consecuencias funestas fue preciso entregar a las gentes una porción de órdenes expedidas en los anteriores correos (...) pero no fue bastante a sosegarlos, por lo que fue indispensable pasar un recado político al $\mathrm{Ilm}^{\circ} \mathrm{Sr}$. Obispo de esta ciudad para que les exhortase a la quietud y tranquilidad (...) parece que quedó el pueblo algo sosegado y aora que son las once treinta no se advierte movimento alguno"

El documento pone de manifiesto el protagonismo del Obispo de Ourense quien va a presidir la Junta (al igual que el de Santiago), compuesta por los notables de la ciudad: corregidor, capitulares (Deán y doctoral), dos regidores, dos militares, dos hacendados y del comercio. Entre estos notables se encuentra Pedro Ventura de Puga.

La Junta se dedica inmediatamente a conseguir fondos para su gestión, como vemos en el siguiente documento dirigido a la Colegiata de Xunqueira de Ambía en el que además se aprecia, en su introducción, como se habían esclarecido los sentimientos de las autoridades:

..."ardiendo en armas toda la España, y pr la necesidad santísima de sostener a costa de su sangre la causa del Señor ultrajada ya pr. El mayor tirano qe han conocido los siglos, la de nro. Amabilísimo jurado Rey D. Fernando $7^{\circ}$, cautivo como en Babilonia pr. las máximas atroces y engañadoras del Emperador más injusto qe pudo abortar la tierra... (se alude también al "avariento y negro carácter del alma de Napoleón")

...se halla formado un Exto. qe pr ser del pueblo de Dios pr su grandeza por su grandeza y por el fervor de su valentía, salga a combatir a este monstruo declarado enemigo de todo nro. bien (...) espera la Junta qe v.m. se sirba suscribir y concurrir inmediatamente y en efectivo a la tesorería de esta Junta, con todo lo que queda en apoyo de un fin tan justo para trasladarlo a la superior noticia de la Suprema del Rno. ${ }^{33}$,"

${ }^{33}$ AHPOR Oficio de la Junta de Orense al Gobernador del Cabildo de Junquera de Ambía, 10 de junio de 1808, Sec. C291 Guerra de Independencia. 
Entre los firmantes se encuentra Pedro Ventura de Puga, Tomás Bobo, comerciante, Luis Folgueras, Canónigo y otros.

Pedro Ventura interviene, pues, desde los primeros momentos en los órganos de dirección del levantamiento, por lo que es de suponer que tuviese ya una actividad pública en el ayuntamiento. No aparece, en cambio, en la lista de donativos recibidos por la Junta. ${ }^{34}$

Del documento anteriormente citado se pueden extraer varias consecuencias:

Que la Junta de Ourense reconoce el carácter soberano de la de A Coruña.

Se confirma el carácter que se le va a dar a la guerra por parte de los absolutistas (aunque de momento no se diferencian las posturas políticas): guerra de religión, guerra santa. Se va a luchar por la defensa del "Altar y del Trono" (Barreiro Fernández, 1976).

La Junta Superior del Reino de Galicia propone la reunión del Reino en Cortes; las 7 ciudades gallegas deben elegir a un regidor, y estos se reunirán el 5 de Junio en A Coruña. Ourense envía a D. Benito $\mathrm{M}^{\mathrm{a}}$ Sotelo Nóvoa, un hidalgo conservador que fue evolucionando hacia posiciones claramente integristas, según Díaz Otero. También D. Pedro de Quevedo y Quintana está presente en esta primera Junta como asociado temporal ${ }^{35}$.

Las tensiones entre la Junta del Reino y la Junta de Santiago van a llevar a la convocatoria de un Congreso Nacional.

La Junta de Santiago, presidida por el arzobispo Múzguiz, que representa las posturas más integristas, no acepta el carácter supremo de la Junta del reino y realiza continuos intentos para entorpecer su labor. Propone, la Junta de Santiago, establecer un congreso de los Estados o Congreso Nacional, reunido por estamentos con participación de la nobleza y el clero como tales, puesto que el pueblo, consideran, ya está representado en el Reino por las ciudades. Se trata, como indica Díaz Otero, de reforzar el carácter noble que ya tenía el Reino y dar al clero un papel dirigente en el proceso político. Son argumentos "tradicionalistas".

El "Reino" está en contra del citado congreso y también las ciudades: Ourense considera que sólo provocará desuniones. Sin embargo, el 4 de Julio opta por convocar el Congreso Nacional y las juntas locales de las ciudades nombran para ello a sus representantes.

\footnotetext{
${ }^{34}$ Lista de donativos recibidos en 1808 por la Junta permanente de Orense. Publicada por B. Fernández Alonso en B.C.M.O., 1906-9, T.III.

35 En una pastoral publicada el 22 de Octubre vemos como ya había modificado su postura con respecto a los franceses a los que califica como "enemigos del Estado, que han mostrado serlo de la Religión”. Fernández Alonso, B.C.M.P., 1908.
} 
Ourense nombra a D. Pedro V. de Puga como representante del estado nobiliario, y a D. Pedro de Quevedo y Quintana por el cuerpo eclesiástico.

Pero el "Reino" modifica su postura, considerando la respuesta contraria de las ciudades, y el 2 de Agosto resuelve "que no haya congreso y que se pase oficio a los Diputados...para que puedan retirarse".

Según B. Fernández Alonso, "el congreso (...) tuvo que disolverse con motivo de la próxima venida de las tropas inglesas perseguidas por las de Bonaparte, hasta su desembarque en el puerto dela ciudad herculina".

Esto es imposible porque el congreso no llega a reunirse y además porque esta persecución no tiene lugar hasta Enero del año siguiente, en 1809.

Lo curioso es que esta explicación de Fernández Alonso está tomada literalmente, aunque no lo cite, de un texto del propio Pedro Ventura.

El caso es que Pedro Ventura debe volver a Ourense y desde este momento no tenemos ningún dato firme de sus actividades, hasta Diciembre de 1809.

En cuanto a la Junta del Reino y demás Juntas de Galicia su situación se va a modificar a partir del 25 de Septiembre, con la constitución de la Junta Suprema Gubernativa Central, que dejará indefinidos los poderes de las Juntas Supremas provinciales.

Pero la posterior invasión de Galicia por parte de los franceses, a principios de 1809 , va a dar fin a este organismo.

\section{- Invasión de Galicia}

La ocupación se realiza en poco tiempo, desde el día 5 de Enero de 1809, en el que entran los franceses en Galicia, el 20 se somete Ourense, hasta el 31 cuando se rinde Vigo, y sin encontrar ningún tipo de resistencia.

Es evidente que, aparte de la clara desigualdad de fuerzas, hubo una falta de organización para evitar, o al menos dificultar, la invasión.

Portela Pazos responsabiliza a la Junta del Reino de la falta de protección de Galicia:

..."entretenida en asuntos de orden secundario, había descuidado el atrincheramiento, en la medida posible, de los puertos montañosos del Este regional, como también las convenientes defensas, ya que no de todas las ciudades amuralladas, de las "plazas fuertes" marítimas, al menos ${ }^{36} \ldots$

A fines de diciembre se urge a la población a un levantamiento en masa.

${ }^{36}$ Portela Pazos, La guerra de Independencia en Galicia, Santiago, 1964. 
Será "la clase humilde la encargada de ser el sostén de las conscripciones", ya que los privilegiados lograrán la no participación abierta en la guerra. En cuanto a la intendencia, los resultados fueron desastrosos, y esta escasez de recursos pone de manifiesto la "escasez de esfuerzos" (Díaz Otero, 1981).

Veamos, brevemente, cómo se desarrollan los hechos:

El mariscal Joaquín Blake al frente del "ejército gallego", no ha podido llevar a cabo su plan de fortificar los puertos de acceso a Galicia para formar una barrera frente a los invasores. Acude a Castilla y después a Vizcaya con 15.000 hombres, siguiendo las órdenes de la Junta General. En Noviembre, después de la derrota de Valmaseda y Espinosa de los Montes, llega a León, perseguido por el general francés Soult, y allí el día 24 entrega al Marqués de la Romana, lo que queda del ejército: unos 8.000 hombres aptos para luchar, ya que el resto estaba afectado por "fiebres malignas contagiosas" debido al hambre, frío y agotamiento.

A partir de aquí, los acontecimientos se suceden rápidamente: Napoleón sale de Madrid el 21 de Diciembre para enfrentarse a los ejércitos de la Romana y Moore.

Ambos ejércitos se retiran entonces por dos puntos, las dos entradas naturales de Galicia: de Piedrafita a A Coruña, por un lado, y de Fuencebadón hacia Ourense y desde aquí, a Vigo. Soult y Ney, los dos generales franceses, persiguen a los fugitivos y penetran en Galicia a principios de Enero de 1809.

A finales de este frío y húmedo mes, las principales ciudades gallegas están ocupadas por los franceses.

En Ourense entra el día 20 el general Marchand, con una división de Ney a su mando, persiguiendo al Marqués de la Romana que se ha refugiado en Portugal después de pasar por Valdeorras, Rúa Petín, Puebla de Trives, Ourense, Allaríz y Xinzo da Limia. A su paso por Ourense son asistidos por la Junta permanente, la cual, por medio de su tesorero D. Lorenzo Taboada, hace entrega al Marqués de Valladares de 400 ponchos, para abrigo del regimiento. Algunos cadetes heridos del cuerpo Literario se retiran al Hospital de Ourense.

En Febrero, Soult decide pasar a Portugal, ya que considera la dominación de Galicia completa. Considera entonces que "si no dejaba libre el Ribero y aún toda la provincia orensana, no podía llevar a cabo su empresa de dominar el Norte de Portugal".

El Marqués de la Romana, llamado popularmente "el marqués de las romerías" por su habilidad en rehuir todo enfrentamiento con los enemigos, se retira el 31 de Marzo a Puebla de Sanabria ante la proximidad de las fuerzas de Soult que va camino de Portugal. Esta retirada es interpretada por algún autor como una liberación: "vióse (Ourense) totalmente de las huestes napoleónicas, pudiéndose afirmar que su liberación ha sido definitiva" (Portela Pazos, 1946). 
¿Dónde se encuentra, mientras se suceden estos hechos, Pedro Ventura?

Es posible que abandonara la ciudad. La llegada de los franceses provoca la marcha de parte de su población:

"No pocos de sus habitantes, conocedores del peligro que les amenaza, habíanse ausentado, entre ellos el muy venerado obispo D. Pedro Quevedo que se encaminó hacia la parte de Entrimo para situarse en la frontera portuguesa".

..."innumerables familias, que, llenas de espanto buscaron refugio en las altas montañas de Santa Marina y otros puntos de la comarca”. (Portela Pazos).

¿Huyó Pedro Ventura de Ourense a la llegada de los franceses?

Según un "Itinerario de un viaje" 37 , escrito por el mismo, podríamos suponerlo así.

El viaje se inicia en Ourense, pasa por Oporto, recorre distintas ciudades españolas para llegar a París; Después Londres y, vuelta a España bordeando la costa mediterránea, para llegar a Cádiz (centro de la revolución liberal y de las Cortes constituyentes).Desde aquí, regresa a Ourense pasando por Madrid.

Este itinerario no presenta ninguna fecha, se indican los días o meses de estancia en cada localidad, y la duración total del mismo es de más de dos años. Es posible que emprendiera este viaje al inicio de la invasión y lo prolongase hasta 1810 .

Otra información sobre las actividades de Pedro Ventura de Puga es la que se refiere a su participación en la organización de las alarmas.

Vázquez Martínez (1943) lo incluye entre los jefes de alarmas:

“una de las primeras alarmas que se organizó fue la de Orense y su provincia motivado al movimiento de tropas que, para contener el avance francés que venía de Zamora, por las Portillas, tuvo que realizar el Marqués de Valladares en Noviembre de 1808 (...) D. Pedro Ventura de Puga articuló los puntos que formaron un reglamento orientado a organizar las alarmas, utilizando para ello al elemento clero, factor tan importante, por su alta misión en las parroquias, primeros lugares donde se hacían las alarmas y además por el carácter religioso que tomaba ya esta lucha que bien pronto iba a adquirir el doble carácter de cruzada religiosa, para reparar tantos sacrilegios, robos y ofensas a la religión"

En 1810 es nombrado Inspector de alarma de Ourense ${ }^{38}$. Pedro Ventura no fue jefe, sino inspector de alarmas.

${ }^{37}$ AHPOR, Sec.Mun. C291. "Itinerario de un viaje de D. Pedro Ventura de Puga", Está sin fechar pero se indican los días y meses de estancia en cada localidad.

${ }^{38}$ Martínez Morás no lo incluye en su relación de Jefes de alarmas, pero sí como Inspector de alarma de Ourense. "Las Alarmas en Galicia", obra inédita consultada gracias a la amabilidad de Carlos Martínez-Barbeito. 
Intervino en la organización de las mismas, pero no participó directamente en ellas.

En resumen, de estos dos primeros años de la Guerra de Independencia tenemos pocos datos de Pedro Ventura. Sabemos que formó parte desde el principio de la Junta de Ourense, que fue nombrado en representación de esta provincia, por el estado noble, a un Congreso Nacional que no llegó a celebrarse, que realizó un largo viaje de Ourense a Cádiz, pasando por Portugal y después por París y Londres y que fue Inspector de alarmas de Ourense.

\section{- Vocal de la Junta Superior de Subsidios, Armamento y Defensa}

La invasión de Galicia por los franceses, había supuesto el fin del "Reino"y la aparición de numerosas juntas locales encargadas del levantamiento en su comarca, pero que no cuajan en un organismo superior, a nivel gallego, hasta Enero de 1810 con la constitución de la Junta Superior de Subsidios, Armamento y Defensa, que tendrá una duración de 3 años. Es en este organismo, donde volvemos a encontrar a Pedro Ventura y donde tendrá sus actuaciones más destacadas.

La situación de Galicia, a mediados de 1809, es crítica. Después de seis meses de resistencia la miseria invade campos y ciudades. Es necesario organizarse para no volver a carecer de un cuerpo disciplinado que puede enfrentarse al enemigo.

A fines de mayo, el $2^{\circ}$ comandante general del Ejército y Reino de Galicia, el conde de Noroña, publica un bando en el que indica que la única autoridad de este Reino es la del Marqués de la Romana, Capitán general y presidente de la Audiencia, y ordena el cese inmediato de todas las juntas locales que "ya no son útiles". Sin embargo, tres meses después convoca la nueva Junta Suprema. Hubo al parecer "una cierta presión por parte de los estamentos privilegiados, de las autoridades ya establecidas", y también los ingleses eran partidarios de ello.

El 17 de Diciembre de 1809 se publica un Reglamento para el establecimiento de una Junta Provincial Nacional y de otras 7 subalternas de Partido. Su objetivo es la representación nacional del Pueblo gallego, dependiente de la Junta Central, que tomase decisiones en el ámbito de la defensa. Su intervención se limita al armamento, defensa y Hacienda (para las nuevas contribuciones extraordinarias), pero sin inmiscuirse en otros asuntos con las autoridades establecidas. Consta de 29 miembros, 20 representan al Estado General y 9 al eclesiástico. Está presidida por el Capitán General y supeditada al poder central ${ }^{39}$.

\footnotetext{
${ }^{39}$ Díaz Otero, Orígenes, estructura y evolución de la Junta Suprema de Galicia, 1808-1816. Santiago, 1981 .
} 
En Ourense, Pedro Ventura recibe un oficio el 27 de diciembre ${ }^{40}$, en el que se le indica se presente para la elección de los representantes de la provincia, y el día 30 cuando tiene lugar la reunión de 18 electores en el ayuntamiento ,

"resultó que D. Pedro Ventura de Puga, regidor perpetuo de esta cuidad tuvo a su favor 16 votos de los 18, otros tantos D. Juan Bernardo Quiroga y Uría (...) diputados representantes por el Estado General de la provincia de Orense..."

\section{0}

Este año parece ser el de más actividad por parte de Pedro Ventura: entre los meses de febrero y junio, viaja a Londres como comisionado de la Junta, y en agosto, se traslada a Puebla de Sanabria para encargarse del abastecimiento de las tropas y la organización de hospitales.

El 22 de enero se constituye la Junta Superior de Subsidios en A Coruña. A esta sesión asisten los representantes de Ourense.

La actividad más intensa de la Junta tiene lugar este año, después decae totalmente, hasta el punto de que ni siquiera sus propios miembros asisten a las sesiones.

La gestión se centra en la necesidad de dinero y hombres. Para conseguir fondos se crea una Diputación de Hacienda y se le encarga que examine un plan de préstamo forzoso de 25 millones de reales. Pedro Ventura forma parte de esta Diputación, junto con los Sres. Umbría, Lamela y Seoane y el $1^{\circ}$ de febrero presentan un informe a la Junta en el que aceptan este préstamo forzoso. El gobierno central había impuesto 120 millones a recaudar en toda España. El empréstito va a jugar un papel decisivo en el sistema de financiación de la Junta, lo que se explica teniendo en cuenta los miembros que la componen. A los privilegiados no les interesa un sistema de recaudación que pueda dañar sus privilegios.

Pero Pedro ventura abandona esta comisión, puesto que la Junta Superior debe atender con urgencia el armamento y decide "enviar comisionados a Inglaterra para adquirir 30.000 fusiles con bayonetas y 5000 sables".

40 "Con fecha del 16 del corriente dirigió el Sr. Gobernador y Comandante general del Reino, al Sr. Gobernador Militar de esta Provincia una orden por la qual crea una Junta Provincial Nacional de Galicia de Armamento, Defensa y Subsidios para 20.000 hombres que manda levantar y otra de Partido en cada una de las capitales; la $1^{\text {a }}$ debe componerse de 29 individuos electos, según la distribución que allí se hace. Entre los vocales electores que han de concurrir a la Junta en donde se ha de elegir reservada y canónicamente dos diputados que representen la Provincia de Orense, ha sido V. M. nombrado entre otros por los parroquianos de Sta. Eufemia la Real de esta ciudad. Y como la Junta electoral se va a celebrar inmediatamente espero (...) se presente V.M. en esta a informarse de la orden y concurrir con su vot a la elección de Diputados... Firmado: Marcos Antonio Bonifaz, 27 de diciembre. AHPOR, Sec. Mun. C291. 


\section{- Viaje a Londres}

Los comisionados son Pedro Ventura y José Connock, pues sabe algo de inglés, pero el responsable, como veremos, es el primero. Salen el 11 de febrero de 1810 y regresan el 18 de junio.Su compañero de viaje, José Connock, colabora en el periódico "Ciudadano"y pertenece al Club de la Esperanza", posiblemente un club masónico; esto le ocasionará problemas a la vuelta de Fernando VII ${ }^{41}$.

Viajan en la fragata Ifigenia, al mando del almirante Juan de Carranza, a quien se le indica que estas dos personas se embarcan para una comisión importante y que deberán ser tratados "con los miramientos que corresponden a su carácter y personas".

Para pagar estas armas y municiones se gestiona con urgencia un crédito (por parte de D. Cesáreo Gardoqui, D. Marcial, Francisco del Adalid, D. Manuel de la Riva Moreno y D. Manuel Díez Tavanera), a favor de D. Pedro Ventura de Puga de 70.000 libras esterlinas en Londres cuya credencial le han entregado a cargo de la casa Garcia's and Lewis de Londres. Pedro Ventura viaja como "Secretary to the Spanish Junta in Spain"42, es, por tanto, el hombre de confianza de la Junta.

El 20 de febrero llegan al puerto de Plymouth desde donde se dirigen a Londres. El 25, están ya en Londres, donde son recibidos por los Sres. Apodaca y García.

Pedro Ventura ve la situación con un cierto optimismo, pero esto no dura demasiado. Con fecha de 21 de marzo envía un oficio a la Junta en el que se queja de la ausencia de noticias y de las dificultades de su gestión:

"la época en que hemos venido ha sido la más fatal y cada vez la hace mas la incertidumbre de las noticias de la península, pr la falta de correspondencia directa. Varias fuentes se dirigen a nosotros, juzgando que nadie pueda tenerlas mas seguros como dependientes de una provincia libre y qdo les aseguramos ntra. ingorancia (sic) y qe desde nuestra salida nada sabemos del pais se quedan absortos"

Solicita el envío de noticias para poder:

"desmentir el fárrago de embustes con qe los diarios Ingleses llenan sus eternos papeles".

\footnotetext{
${ }^{41}$ Aparece como miembro de la "Lista de los enemigos mas furiosos de la Religión y del Rey que hay en La Coruña", elaborada en 1814. Barreiro Fernández, Hª Contemporánea de Galicia, TI, 1982, pág.174.

${ }^{42}$ Pasaporte de D. Pedro V., 20 febrero de 1810. AHPOR, Sec. Mun. C291.
} 
Y se refiere a la espinosa cuestión de la falta de reconocimiento por parte de Galicia del Consejo de Regencia:

"el ministro nos dio a entender havía tenido algn recelo de qe Galicia queria hacerse independiente"

Y aunque, al parecer, quedó satisfecho de la respuesta dada por los comisionados, no se les comunicará nada mientras no vuelva a Inglaterra una fragata enviada a Galicia para

"saber de cierto si se habia reconocido la Regencia"

La Regencia se constituye el 19 de marzo y la Junta Superior de Galicia no la reconoce hasta el 28 del mismo mes; actitud con la que no está conforme Inglaterra que prefiere negociar con un Gobierno Central.

Por tanto, sí había rumores en este sentido aunque Díaz Otero considere que no tienen fundamento y demuestre fehacientemente la subordinación de la J.S. de Galicia a la Central.

En abril vuelve a dirigirse a la Junta desanimado por "la estancia tan larga y dilatada con poco o ningún fruto hasta el presente, la falta total de correspondencia con Galicia".

Así es que durante dos meses la Junta no se pone en contacto con sus comisionados.

Sin embargo, el objetivo de su misión se lleva a cabo y, a fines de mayo, salen de Londres para emprender el viaje de regreso en la misma fragata.

Veamos ahora el balance de su gestión; cuentan con un crédito de 70.000 libras esterlinas (5.950.000 reales), para comprar las siguientes armas y municiones:

4000 quintales de pólvora para fusil y cañón, 3201 quintales ingleses de plomo para Valeria, 12.000 fusiles, 3.000 sables, 12.000 fornituras, cartuchería y 2otros efectos debidos a la magnitud (sic) de S:M:B., que , por lo tanto no se incluyen en los gastos.

Las cuentas son presentadas el 15 de diciembre, siendo Pedro Ventura vocal secretario de la Junta, en un documento que se hace público.

Gasto de 45.419 libras, 13 chelines y 4 dineros, repartido así:

2.748.18. 11

. Gastos de la fragata en Plimouth "sus reparos y habilitación, víveres para la tripulación, vestir a la tropa y gastos de los Sres. Comisionados en Inglaterra. 
73

42.597. 13. 7
.. Gastos menores por cargas y descargas en Plimouth.

. . Por coste de 4.000 barriles de pólvora, 3.201 quintales ingleses de plomo y 30 moldes para hacer balas (incluyéndose la rebaja del $10 \%$ por pronto pago).

Importe total: 45.419 .13 .4

El pago de esta cantidad se realiza así:

15.869. 6 valor de 7 letras de cambio sobre Londres que tomó la Real Aduana en pago de derechos que ocasionó en ella en el mes de abril un buque habilitado para Veracruz.

6.014. 15. 11 y medio, valor de otras 3 letras por iguales razones de habilitación de otro buque en el mes de julio.

23.535. 16. 10 y medio, libras esterlinas que la Junta ha entregado a los comisionados en partidas de plata labrada (...) y el resto de 199.558 rs. y $25 \mathrm{~ms}$., en un libramiento sobre la J. Provincial de Santiago para completar el pago al comisionado de Londres en las últimas letras libradas.

Que suman el total de 45.419. 13. $4^{43}$

Las cuentas resultan perfectas, como es de esperar en un documento expuesto al público, que adquiere un cierto carácter publicitario, al ser publicado en un momento de disminución de las atribuciones de la J. S. Es, de todas formas, una de sus actuaciones más destacadas.

La relación de gastos es poco detallada: se engloban en una misma partida los gastos de los comisionados y de la fragata; en cambio, se especifican a parte, 73 libras de carga y descarga. Sin embargo sabemos que la tripulación de la fragata tuvo problemas para cobrar las pagas que se le debían desde La Coruña: en un oficio de los oficiales de la fragata Ifigenia a su comandante, aducen estar "faltosos de ropas y los mas de ellos enfermos".

La situación del comandante debía ser más desahogada, puesto que solicita de Pedro Ventura "qe se me auxiliase con alguna cosa pr cuenta de la Comisión pa. que pudiese responder a aquellos (los obsequios de otros jefes de Plimouth) y este es un honesto pretexto pa. hacerme algún señalamt ${ }^{o}$ pa los gastos de mi biaje de

${ }^{43}$ Estado que la J. Superior del Reino de Galicia manifiesta al público del coste y pago en Londres (...) conseguidos mediante diligencias personales de su comisionado...AHG Guerra Ind. C 29, leg.32. (Doc. Reproducido también por López Ferreiro en T. XI Anejo). 
ida y buelta a la capital, qe no son de mucha cantidad respeto a qe solo ascenderan a 50 libras".

Y más adelante, en otro oficio vuelve a pedir 36 libras "a fin de subvenir con ellos los gastos qe debo hacer pa nuestro regreso”, que Pedro Ventura libra rápidamente.

No hay una correspondencia entre el total de los gastos y el crédito concedido. Desconocemos en que se gastó la diferencia que resulta: 24.581 libras esterlinas; en un oficio del 16 de abril, Pedro Ventura pregunta "en que artículos quiere que se invierta lo sobrante que queda después de remitir los 6000 quintales de pólvora de que venimos encargados".

De los 6.000 quintales que se esperan comprar, sólo se obtienen 4.000, en cambio, las armas son donación del gobierno británico.

Apodaca indica que "el importe de armas y municiones se comprenderá en la cuenta general pendiente entre España y la Gran Bretaña."

En lo que respecta a Pedro Ventura podemos afirmar que aparece como el hombre de confianza de la Junta. Es a quien se le concede el crédito de 70.000 libras, el que administra el dinero en Londres como representante de la misma y, por último, el que presenta las cuentas al final de la gestión.

Los gastos de Pedro Ventura en Londres se incluyen en la cuenta general, no fueron por tanto sufragados por él mismo como indica varias veces Fernández Alonso. Desconocemos su cuantía; la dieta de los representantes especiales del gobierno central era de seis duros diarios, es decir, 120 reales (Martínez Morás 1955).

Sabemos que fueron objeto de crítica por parte de algunos españoles residentes en Londres, como refiere un tal John Smallwood en una carta dirigida a D. Pedro una vez que este ha regresado a Galicia:

"Siento mucho el decir a V.M. que poco después de su partida he oído entre algunos Españoles que V.M. y su compañero habian gastado muchísimo dinero; yo les he respondido que sabía muy bien que V.M. buscaba todos los medios de economía y que seguramente ningún Español pudiere vivir más estrechamente en Londres conforme a su oficio distinguido de Diputado." 44

No sabemos si las críticas tienen o no fundamento, aunque el mismo J. Smallwood se refiere más adelante a que "ya he pagado las cuentecillas que V.M.( D. Pedro) dexo".

443 septiembre 1810 AHPOR, Sec. Mun. C291. 
Pedro Ventura llega a A Coruña, a bordo de la misma fragata el 14 de Junio, su misión ha durado casi cuatro meses. Pocos días después emprende viaje a Ourense con el consentimiento de la J.S. según oficio firmado por el arzobispo de Santiago.

En este momento la Junta ya no cuenta con todos sus miembros, del total de 25 , hay 10 ó 12 de modo permanente, así es que en el mismo oficio se le indica a D. Pedro "esperando de su acendrado patriotismo regresara (...) a la mayor brevedad”.

\section{- Diputado a Cortes}

La Junta debe ahora resolver la cuestión de la convocatoria a Cortes para lo cual oficia a todos los vocales ausentes, para que estén en A Coruña el día 20 de julio, con objeto de nombrar Diputado a Cortes por dicha Corporación. Se reúnen al fin, el 30 de julio, 18 vocales y su presidente, "solo faltan Oliva, el Arzobispo, Lamela, Rosal, Puga y La Riva, que han dado poder a varios compañeros”.

Efectivamente, Pedro Ventura desde Fontefiz excusa su asistencia en un poder dado ante escribano en el que dice lo siguiente:

"que en atención a la notoria y casual indisposición que (...) le sobrevino y actualmente está sufriendo y padeciendo procedida de un golpe de la caballería avajo en que venía montando al regresar a dcha. Ciudad de Orense desde La Coru$\tilde{n} a(. .$.$) de cuias resultas aquel se está curando y medicinando, no puede por aora$ pasar personalmente a presentarse en la J.S. de este Reino (...) para votar (...) en orden a la elección y nombramiento de Diputado a Cortes" 45.

Otorga su poder y voto a D. Vicente Lamas de la Torre, representante por la provincia de Mondoñedo.

Salen elegidos, D. José Alonso López, D. Cosme Rodríguez Seoane y D. Pedro Ventura de Puga, de los cuales sólo el primero; Alonso López, irá a Cádiz como representante de la J. S., al resultar designado en posterior sorteo.

Por tanto, Pedro Ventura no viajará a Cádiz. Los representantes de Galicia en las Cortes no tendrán un papel muy lucido (Barreiro Fernández 1982) y tampoco contaron con el apoyo decidido de los organismos oficiales; van a tener grandes problemas en el cobro de sus dietas. Alonso López, aunque estaba al corriente de sus dietas, en 1812 no tenía ni para las Gacetas.

\footnotetext{
${ }^{45}$ Certificado de D. José Anto. Rivadeneira, Srio. de la Junta S. de la elección de D. Pedro como Diputado a Cortes; expedido a petición del mismo. 7 septiembre 1810. AHPOR C 9706.
} 


\title{
- Comisión a Puebla de Sanabria (agosto de 1810): la situación del ejército
}

La Junta Superior, que continúa teniendo como objetivo prioritario la ayuda y fortalecimiento del ejército, envía para ello representantes suyos cerca de las tropas que operan en la frontera.

El 4 de agosto, en un oficio dirigido a D. Pedro, le indica la urgencia de que se atiendan las necesidades de la división del General Taboada por parte de un vocal de la J. S. y que

\begin{abstract}
"acaba la misma de nombrar a V.S., y acuerda comunicárselo para que pase inmediatamente al Cuartel General de dicha División y que informándose por si mismo de los objetos y atenciones de ella por todos sus ramos de Hacienda, Provisiones Y hospitales, proceda en unión y de acuerdo con su General, a reformar los abusos que encuentre, corregirlos, facilitar subsistencias y todo lo demás que sea preciso".
\end{abstract}

Las facultades que recibe son pues muy amplias.

En realidad, la propuesta de nombrar a Pedro Ventura, procede del propio general Francisco Taboada y Gil, según otro oficio recibido en Ourense dos días antes. Desde su cuartel general de Lubián, el general indica que ha sido atacado el 29 de julio por el enemigo "con fuerzas muy superiores" y que ha tenido que replegarse desde La Puebla, donde se hallaba, a la Portilla del Padornelo y, desde aquí, piensa trasladarse a la de La Canda por ser de más fácil defensa, pero que se halla "absolutamente sin medios para hacerlas subsistir (a las tropas), y que sería muy conveniente que (D.Pedro) pasase a Verín para proporcionar las subsistencias necesarias."

Para conocer la gestión de D. Pedro en la división del general Taboada, contamos con una serie de oficios que se cruzan entre la J. S. y la Junta de Orense con Pedro Ventura y otros entre este y. Francisco Taboada y con José Ceferino Bringas, Comisario de Guerra de esta división; Felipe Mate, encargado de carnes para consumo de la tropa; José $\mathrm{M}^{\mathrm{a}}$ de Arce, Intendente de Zamora; Lorenzo Taboada y Moa, comisario, administrador de Bulas de Ourense y miembro de su Junta.

La división del general Taboada, situada en La Puebla, ocupa un lugar estratégico importante para la defensa de Galicia: la posibilidad de un nuevo ataque es bastante real mientras los franceses permanezcan en la península.

La provincia de Ourense (con la de Lugo) es la principal entrada de Galicia por los puntos de Domingo Floréz y las Portillas del Padornelo y La Canda.

Es, precisamente, por Domingo Floréz por donde entra a principios de enero del año anterior, el Marqués de la Romana perseguido por el general Marchand, y por el segundo punto sale a principios de marzo del mismo año hacia Puebla de Sana- 
bria, huyendo de Soult; y en junio, sale Soult de Galicia desde la Gudiña a Puebla de Sanabria.

Por tanto, cabe pensar que el envío por parte de la Junta Superior de un vocal suyo a esta división, para procurar el abastecimiento de las tropas y la organización de hospitales, es considerada una misión importante y, en consecuencia, se le proporcionarán medios para desempeñarla. No es así. La Junta no envía fondos a D. Pedro, indica a la de Ourense que se los suministre y ésta no envía más de dos mil duros (40.000 reales). Así es que la gestión de Pedro Ventura finaliza en cosa de un mes por falta de caudales.

En primer lugar, veamos cuál era la situación de los soldados en palabras del propio general Taboada:

"en el invierno pasado han muerto del corto Ejercito que había en el Reino, más de 4.000 hombres (...) dicha mortandad fue originada de la continua fatiga, el servicio, por nieves, aguas, fríos, escaso alimento, falta de Prest. sin vestuario ni abrigo, y menos calzado con que poder resistir y precaver semejantes infortunios".

Carranza describe también esta situación:

"me ha estimulado a tomar el partido de cubrir las desnudeces en que están con chaqueta y pantalón y sombrero(...) pero como carecen de camisa, zapatos y medias...

Sobre las penalidades de los soldados hay un completo acuerdo; en la representación que la J. S. hace al Consejo de Regencia (15 de diciembre de 1810), para solicitar grano, en la que probablemente esté la opinión de Pedro Ventura, se llega a justificar la deserción cuando el soldado no recibe alimento:

"El soldado bien mantenido no teme por lo regular al peligro (...) desde que las privaciones suceden a la abundancia ya se les oye maldecir su situación, mira con desprecio el servicio militar y concluye por último con abandonar sus banderas para buscar en otro destino el sustento de que carece, sin que, por esta deserción, pueda apenas hacérsele cargo, porque con razón dirá no está obligado al contrato que estipuló con la Patria, ya que ella misma faltó primero a las condiciones de él” .

(Reproducido por Martínez Morás, pág. 112)

Si la situación del soldado es precaria, la de la población civil no lo era menos. La guerra trae consigo una enorme escasez de grano, y eso en un país deficitario tradicionalmente en este producto. Por otra parte, las requisiciones a los pueblos se seguían haciendo como algo habitual para procurar el abastecimiento del ejército y suponen “una plaga terrible para los pueblos”, com afirmaba Pedro Ventura. 
Este será, por tanto, su objetivo fundamental: proporcionar víveres. Medios con los que cuenta: 40.000 reales entregados por la Junta de Ourense, de los cuales 10.000, se destinarán a la creación de un pequeño hospital en Verín y los 30.000 restantes a la compra de granos; además, 20.000 reales que aporta el Intendente de Zamora, Sr. Arce.

En total son 50.000 reales, cifra que, como indica Pedro Ventura no da más que para "principiar acopios". Para valorar esta cifra hay que señalar que la dieta de los representantes especiales de la Junta Superior al gobierno central o al británico era de 43.200 reales anuales, es decir, la dieta de un solo individuo.

La comisión comienza en Lubián, a donde llega el 12 de agosto, y desde allí informa de la retirada de los franceses. El día 16 está en Puebla, una vez que ésta ha quedado libre.

Comunica la instalación de un hospital de 20 ó 30 camas en Verín, por parte del comisario D. Lorenzo Taboada, "para proporcionar la curación de los enfermos peligrosos que no pudiesen seguir su viaje a Orense”.

Crea una factoría de provisiones, nombrando factor a D. Nicolás López de Vila, para la cual inicia la compra de granos en Castilla (en Mombuey), donde se encuentran más baratos, en previsión del cercano invierno.

El hospital de San Martín de Castañeda, situado a dos leguas y media de la Puebla, es el siguiente destino. Allí se desplaza el 25 de agosto con el comisario de guerra D. José Bringas.

Lo encuentra "limpio y en lugar saludable, (pero) muy falto de ropas, trigo y dinero con que satisfacer las cargas necesarias de su instituto”. El hospital está regentado por las monjas del mismo monasterio y su gestión es alabada por Pedro Ventura: "lo administran por cuenta de la Real Hacienda pero con una economía y celo verdaderamente religioso y digno de todo encomio". Las estancias resultan "cuando más a seis reales".

Recibe del Intendente, Sr. Arce, una copia de las últimas cuentas. Al hospital, desde que está a su cargo la asistencia de militares enfermos, se le han entregado por parte del ejército, 32 reses vacunas grandes y 92 fanegas de trigo. Pedro Ventura ordena que se le entreguen: 51 vacas y de 26 a 30 reses menores, sobrantes de las raciones "que la paga de los soldados economizó y cuya devolución a los pueblos causaría disturbios y cuestiones por haberse gastado parte de los exigidos,(...) sin poder suministrarles otra cosa por falta de medios (queda) surtido de carne para algunos meses".

En cuanto a "reformar los abusos", la actuación de Pedro Ventura se centra en dos puntos:

El primero se refiere a un tal Chavarria, "jefe partidario", quien, "con su pequeña división formada a costa del ejército de la Izquierda se hace obedecer y temer de todos estos pueblos". Sus tropas hacen "más daño a los habitantes de Sanabria 
que perjuicios a los enemigos”. El poder de Chavarria es tal que impide que el Intendente proporcione "algunos miles de fanegas". Por lo tanto, D. Pedro sugiere a la Junta Superior que represente al Marqués de la Romana y a la Regencia, ya que este jefe se dice comisionado del Marqués y de la Junta Central, "precisándole a cesar en sus funciones para que se cree autorizado". ¿Se trata de abusos de las partidas o de un roce de competencias con el ejército? ${ }^{46}$

El otro punto es de orden interno del propio ejército. Felipe Mate, encargado del ramo de carnes para el consumo de la tropa, presenta un informe a D. Pedro en el que da noticia de los víveres de la división con algunas incongruencias: no sabe el $\mathrm{n}^{\mathrm{o}}$ de reses de ganado y cueros con precisión, porque no ha tenido tiempo de reunirlos y contarlos aún el 25 de septiembre, cuando desde el 16 está ya libre de enemigos esta zona; e indica además: “debía haber muchos más cueros”.

Ante lo cual, Pedro Ventura comunica a su superior, D. José de Arce, que le ordene "remita sin dilación alguna los ganados que tenga en su poder, (51 vacas y 26 reses menores) al Monasterio de San Martín de Castañeda (...), sin perjuicio de qe V.S. como instruido en el número de reses y más efectos (...) pueda tomarle cuentas". ${ }^{47}$

Abuso, sí debió haber, ya que Arce toma las medidas oportunas y responde a D. Pedro en el mismo día: "he prevenido a D. Felipe Mate, encargado qe ha sido hasta ahora al ramo de carnes..." 48

El 5 de septiembre comunica a la Junta de Ourense su propósito de recorrer el país hasta Domingo Flores y desde aquí a Ourense, para ver "en qe sitios se podrán colocar almacenes y hospitales en caso de retirada a las Portillas y que hayga dinero, todo en cumplimiento de las órdenes de la J. S. y oficios del Mariscal Taboada”.

Es Taboada quien urge a Pedro V. sobre la necesidad de aprovisionar "trigo, centeno, cebada, patatas y castañas" y fabricar vestuarios, ropas y zapatos, por la proximidad del invierno, así como, almacenes y hospitales. También es necesario que haya aguardiente, "pues un poco qe se le de al soldado en el rigor del invierno, cuando tenga fatiga o quiera entrar en acción con el enemigo, que le anima de tal modo que enviste ofendiendo intrépidamente a dcho. enemigo”.

Así pues, Pedro V., se traslada a La Mezquita y, desde allí, hace presente a la J.S. la necesidad de vestido y calzado para la tropa, "sin cuyos requisitos se exponen los soldados, como el año pasado a la mortandad de Villafranca ocasionada de estas faltas, evitándose con el surtido de ropas y calzado enfermedades destructoras".

\footnotetext{
46 Martínez Morás, "Las Alarmas en Galicia”, nos habla de que "una vez extinguido el período de prestigio y autoridad de las J. provinciales, el poder militar invadió todas las esferas.

${ }^{47}$ Oficio de Pedro V. a D. José Arce, Intendente y encargado de las provisiones de la división por no haber en ella ministro de hacienda, 26 agosto 1810, AHPOR, Sec. Mun. C 291.

48 Oficio de D. José de Arce a D. Pedro, 26 agosto 1810, AHPOR, C 9706.
} 
En respuesta, la J.S. pasa oficio al Intendente del Reino para que remita a esta división 3.000 pares de zapatos y recomienda a la Junta de Ourense "trate de recaudar con la mayor actividad ropa para camas".

Posteriormente, Pedro V. informa de los sitios más a propósito para instalar almacenes: en Castromao en la casa del abad, en Valdeorras, en Sobrado de Trives, en Verín, en la Mezquita y en la casa del Marqués de Castelar, en el valle del Conso; y hospitales en el convento de Correjanes (este hospital recibirá heridos de la división del Centro) entre O Barco y A Rúa, y en el monasterio de Montederramo. La creación de almacenes se quedará en mero informe.

A finales de septiembre, viendo la imposibilidad de realizar su misión, ya que la J.S. no proporciona ningún medio y la de Ourense está exhausta, determina, según sus propias palabras, "usar de aquellos remedios y preservativos contra los efectos funestos qe puede producir mi golpe, cuyas medicinas suspendí, por la urgencia con qe V. Exa. suponía necesitaba la división de Sanabria de la presencia de un individuo de la J.S." Es decir, vuelve a su casa de Fontefiz.

¿Cuáles son las conclusiones que podemos extraer de todo esto?

En primer lugar, queda patente la falta de coherencia de la J.S. al enviar a Pedro V. a esta misión sin fondos para llevarla a cabo. Repetidas veces Pedro V. alude a sus proyectos, "caso que haya fondos", o "habiendo fondos". La ayuda de la J.S. se limita al envío de los 3.000 pares de zapatos y envíos de dinero "solo para la plana mayor".

Pedro Ventura espera inútilmente recursos: "los auxilios indispensables al objeto para que se me destinó aquí". La Junta Superior de Ourense es la que corre con los gastos de dietas de Pedro Ventura y de compra de granos.

Esta actitud por parte de la J.S. está en relación con su desastrosa situación hacendística. La Junta Superior se ve impotente para hacerse con fondos procedentes del normal funcionamiento de la presión fiscal: Por ejemplo de la Contribución "subrogada de guerra" calcula obtener 3 millones de reales mensuales y, a ines del año 1811, se han recogido 14.000 reales. Esto hizo que se recurriese al sistema de empréstitos como medio de financiación. Y en el año anterior de 1810, se esperaba reunir 30 millones de contribución patriótica, pero entre enero y junio se ingresan sólo 5.500.656 reales. (Díaz Otero).

La Junta Superior es incapaz de afrontar esta situación:

"Finaba agosto de 1810 y veía agotados sus recursos; veía el país empobrecido y sus habitantes agotados por todas partes, las cosechas misérrimas, la industria y el comercio casi paralizados; y frente a esto la Patria en peligro, el Ejército mal vestido y peor alimentado; oía las quejas de los soldados y leía las reiteradas peticiones de sus caudillos; consideraba el miserable estado de los hospitales..." (Martínez Morás). 
En segundo lugar, en vista de los resultados obtenidos, es de suponer que se seguirá utilizando la requisición como medio de avituallamiento del ejército. Es, por tanto el pueblo el que seguirá soportando el peso de la economía de guerra. Además, esta situación se agrava por las medidas que toma la J.S. para obtener fondos: impuestos extraordinarios que principalmente gravan al comercio, lo cual encarece los precios al consumo y repercute por igual en el conjunto de la población...de recursos muy desiguales.

Por último, la cuestión de las dietas de Pedro Ventura: son sufragadas por la Junta de Ourense a la cual devuelve el 14 de octubre, 3.420 reales "resto de 6000, que por esta Junta le habían franqueado para su viaje al punto de Puebla de Sanabria”. Es decir, Pedro Ventura gasta 2.580 reales en menos de un mes (desde el 10 de agosto al 3 de septiembre), lo que viene siendo un gasto de más de cien reales diarios. La dieta de los representantes especiales era de 6 duros diarios (120 reales).En todo caso no fue su patrimonio, como afirmaba Fernández Alonso, el que respondió de estos gastos.

El día tres de septiembre tenemos ya a Pedro Ventura en su casa, dedicado a las tareas de recolección del vino.

\section{- Reducción de la Junta Superior: Inspector de Alarmas}

Pedro Ventura, secretario de la Junta e inspector de alarmas.

Pedro Ventura será miembro de esta nueva Junta desde el 4 de octubre de 1810 hasta enero de 1812.

El 17 de junio se promulga una R.D. que dispone la reducción de las Juntas Superiores al número de nueve vocales y las provinciales a cinco. A pesar de las protestas, por parte de la Junta Superior de Galicia ante el gobierno central, el 4 de octubre se procede a esta reducción.

La reducción no sólo afecta al número de miembros, sino también a sus facultades. Al mismo tiempo, se amplían las del Capitán General. La disminución de facultades trae consigo el desánimo de sus vocales hasta el punto de que es necesario "llamar repetidas veces a los ausentes".

Los nueve miembros se reparten entre las siete provincias, más el arzobispo de Santiago, Rafael de Múzquiz, y el Intendente, Cesáreo Gardoqui. Continúa el predominio de los estamentos privilegiados, siete nobles, y el clero; desaparecen, en cambio, los representantes mercantiles que había en la composición inicial de esta Junta.

Por Ourense, vuelve a ser elegido Pedro Ventura de Puga. Sin embargo, no se traslada a A Coruña para realizar su tarea como miembro de la J.S. a pesar de los 
repetidos oficios de la misma. Ya anteriormente, para la elección de vocales, había excusado su asistencia en un escrito en el que lamenta haber recibido tan tarde el oficio de la J.S. y que, además, le hubiesen cogido "sangrado de una mano dos días antes". Da poder D. Vicente Lamas (al igual que antes para la elección de diputado a Cortes) y explica que la causa de su ausencia son los trabajos agrícolas: "Como haora nos hallamos en la recolección del vino y siendo este genero principal fondo de mi haver y de qe depende no solo mi subsistencia sino también la de mi familia", y la necesidad de mejorar su salud.

Por fin, el 14 de noviembre se encuentra ya en A Coruña, donde presenta un informe sobre la necesidad de que "se filien los jóvenes qe estan en la primera clase" para no aumentar los gastos públicos y contar con un ejército de reserva en Galicia.

Problemas con los jefes de alarmas:

La Junta Superior se va a enfrentar a fines de 1810 con un problema con los jefes de alarmas. Es precisamente en estos momentos cuando Pedro Ventura es nombrado inspector de Alarmas.

La Junta Superior tiene conocimiento, por oficio de la Junta de Ourense, se una conspiración entre los jefes de alarmas de la provincia de Ourense. Son las partidas de Cuesta de Laxinde, Coldebergazo, Cotobad y Montes, quienes convocan a otros jefes de Corneda, Mardamas y Lobanes a una reunión el día 8 de diciembre en el lugar de Doade (término de la jurisdicción de Montes). ¿Cuál es el carácter de esta conspiración? Según un anónimo que recibe la Junta: "Mas alla de Santiago está la fragua, y los materiales y de la parte aca se hallan algunos de los Ajentes tanto mas nocivos, quanto son de Carácter, Individuos de Juntas, Gefes de Alarma, y qe Bocinglean Patriotismo al paso que son devorados de la ambición, y rebeldes a la subordinación".

Los datos del anónimo informante, que se proclama "un verdadero patriota" y fiel a las autoridades de Cádiz y La Coruña, no son muy reveladores, pero la Junta debe considerarlos importantes ya que decide enviar circulares a las Juntas Provinciales y a los Obispos, así como a uno de sus vocales a las provincias de Santiago y Tuy "a fin de averiguar los autores de la trama". Envía, además, un parte a la Regencia.

Es D. Cosme Antonio Rodríguez Seoane, representante de la provincia de Tuy, quien informa a Pedro Ventura y a la Junta. Indica que, "convenia separar de aquel pais a D. Gregorio Cordero porque los alborotaba, y descaminaba con sus conbersaciones materiales". En Vigo, D. Francisco Xavier Vázquez, alcalde del crimen, había salido con tropa la noche anterior lo que sorprendió a algunos; que hubiera un lance entre D. Cayetano de Limia, jefe de alarma de Bouzas y el coronel de Orense, pero que ahora estaban en armonía y acuerdo; que el Sr. Martinen- 
go puso "la noche de ayer la alarma de la capital sobre las armas" y aunque, al fin, todo se calmó, llegaron rumores a Tuy de que las alarmas de Vigo iban a conquistar la ciudad. En suma, muestra su satisfacción por comprobar que "no se ha estendido a esta Provincia la semilla contrarrevolucionaria" y añade por último la conveniencia de "recoger la persona de D. Manuel Orxe, Abogado vo de Sta. M" de Touron en el departamento de Laxinde y sea o no acreedor a ello, porque se me aseguro por sujeto de toda mi satisfacción era un perorador de muy mala fe y que causaba acaso la mayor parte del daño que se transmitia a los paisanos".

¿Qué valoración podemos hacer de este episodio? No hay noticias bibliográficas que se refieran a problemas con las alarmas (salvo la obra inédita de Martínez Morás). En todo caso, no sabemos cuál puede ser el alcance de esta conspiración.

Inoperancia de la Junta Superior:

A partir de los primeros meses del año 1811, la Junta se muestra inoperante, con sus funciones muy reducidas hasta el punto de que llega a pedir, en el mes de marzo, su disolución. Se queja, además de las competencias y abusos del Intendente y Capitán General.

La actividad de Pedro Ventura en la misma también se reduce. Permanece en su cargo de secretario de la Junta Superior hasta principios de febrero, cuando se le concede "permiso limitado a corto tiempo para que pasase en su casa con objeto de arreglar sus asuntos domésticos". Pretende en este momento que las Cortes lo exoneren del cargo de vocal de la Junta, lo que se le deniega. A partir de aquí la Junta le envía repetidos oficios para que se reincorpore, llegando incluso a decirle que si no regresa "se vera en la situación de disolverse".

Pero Pedro.V. contesta que los diversos males que lo aquejan se lo impiden: primero una fiebre catarral, ocasionada por el temporal que sufrió en su viaje, una " fluxión de la cabeza y una capa de diviesos, fruta muy común este año por este pais, tan pronto como me deshaga de esta incomoda y enfadosa plaga cumpliré mi deber".

La Junta continúa enviando oficios, ante lo cual Pedro V. afirma que "el patriotismo y los servicios pueden llegar a un punto pero de allí no pueden pasar; mientras estuve sano serví p(er)o al hombre enfermo le sobran trabajos con estarlo. Los diviesos han disminuido pero (le han sobrevenido) unas tercianas que, aunque tratadas con quina y algunos cocimientos amargos, (lo han dejado) débil y con dolores de cabeza y(le) hacen imposible desempeñar las funciones de secretario de la J.S”.

A finales de mayo vuelve a ocupar su puesto y en él permanecerá hasta el mes de agosto. En este momento, la Junta se encuentra muy disminuída en sus funciones y llega a pedir, el $1^{\circ}$ de marzo, "su disolución, si es inútil", y se queja de las "competencias y abusos del Intendente y Capitán General". Hay pues, un choque de competencias entre las dos instituciones. 
¿Cuáles son los asuntos tratados por la Junta?

Negocia con el general Xavier Abadín acerca del traslado de la Junta. Pedro V. es partidario del cambio a otro lugar, "donde la subsistencia fuese mas acomodada a la escasez, con qe. algs. de los individuos (tienen) qe. vivir pr. no darles sueldo la nación, ni eximirlos de ninguna de las contribuciones impuestas, pr. el servicio qe. hacen". Sin embargo, no se toma, por el momento, ninguna decisión por estar sólo 5 de los 11 que integran la Junta.

Pedro V. disculpa el hecho de que la junta no pueda atender "los inmensos gastos de la guerra", a pesar de ser su objetivo fundamental, debido a la actitud del gobierno central, "qe. nos ata las manos en punto de contribuciones" y al enorme déficit de las rentas. Según su propios datos, el presupuesto del ejército asciende a cerca de 9 millones de reales mensuales (sin incluir la Marina: 90.000 reales) y los ingresos a 50 millones "un año con otro".

El 9 de junio se aprueba la contribución extraordinaria de guerra. Se promulga un decreto sobre confiscación de bienes a los afrancesados.

La Junta se convierte en un organismo de gestión poco eficaz. Ante la consulta de una Comisión Provincial sobre las formalidades que deben observarse con los forasteros, responde que esto corresponde al Corregidor y que ella "nada puede decidir".

En enero de 1812, Pedro V. cesa en su cargo al disponer la J.S. que los diputados de Lugo, Mondoñedo, Ourense y Betanzos, salgan en esta fecha sin entrar en suerte "como nombrados por el pueblo desde la $1^{a}$ instalación de la J."

La actividad de la Junta Superior durante la guerra de Independencia supone la participación de la clase dominante gallega en la vida política del país. La Junta Superior de Reino es un organismo revolucionario sólo desde el punto de vista jurídico (por lo que supone de reconocimiento de la soberanía emanada del pueblo), pero no desde el punto de vista social ya que en este sentido supone la continuación del orden establecido (Díaz Otero). El levantamiento es considerado por el Reino como una fuerza dirigida a aplastar los "males" de la Revolución francesa, por tanto de carácter contrarrevolucionario.

La participación de Pedro V. en este organismo, es pues algo coherente como miembro de la hidalguía. No conocemos su postura ideológica en el mismo. Pero sí sabemos que no debió de tener problemas con el regreso de Fernando VII y la vuelta al absolutismo, ya que en vísperas del trienio constitucional se halla ocupando su cargo como regidor en el ayuntamiento de Ourense.

Sin embargo, su compañero de viaje a Londres, D. José Connock, sí tiene una adscripción política clara. Pertenece al "Club de la Esperanza", posiblemente un club masónico y es ayudante del periódico "Ciudadano". Se encuen- 
tra además entre los miembros de la "Lista de los enemigos mas furiosos de la Religión y del Rey que hay en La Coruña", elaborada en 1814 cuando se inician las depuraciones y persecuciones de los liberales ${ }^{49}$ ¿Conocía Pedro Ventura las teorías de su compañero? Era difícil que las ignorara después de estar casi cuatro meses juntos, sobre todo en un momento en el que aún no eran peligrosas, como se hicieron luego con el regreso de Fernando VII y la reposición del absolutismo.

Lo que sí sabemos de Pedro V. después del episodio de la guerra de Independencia es su pertenencia a la Sociedad Económica de Amigos del País de Santiago, según un recibo del año 1814.

La Sociedad Económica de Amigos del País de Santiago se funda en 1784 y los últimos años del siglo XVIII y el primer tercio del XIX suponen una época de decadencia en este organismo ${ }^{50}$; el año 1813 marca un hito en esta situación de hundimiento y el inicio de sus actividades, pero "sucumbió al período de reacción del año siguiente"(Fernández Casanova,1981). Las listas de socios se hacen a partir del año 1834, y Pedro V. no aparece en ellas. Sí aparece el ayuntamiento de Ourense en 1858 en los suscriptores a la "Revista Económica".

\section{PARTICIPACIÓN EN EL RÉGIMEN LIBERAL}

El Trienio Constitucional encuentra a Pedro Ventura de Puga ejerciendo su cargo de regidor en el Ayuntamiento de Ourense junto con el marqués de Villaverde, Luis Álvarez Pestaña, D. Juan Antonio Saco y D. Antonio Arias. Tiene 45 años.

La ciudad de Ourense al igual que otras ciudades episcopales no se pronuncia y tiene que ser tomada por las armas. Al entrar las tropas "hallan una ciudad desgobernada ya que el ayuntamiento estaba cerrado por haber huído los regidores" (Barreiro Fernández 1982).

\section{- Diputado en 1821}

A pesar de haber formado parte del extinguido ayuntamiento, se incorpora pronto a la vida política, primero como miembro de la Diputación de Galicia en 1821 y luego de la de Ourense.

\footnotetext{
${ }^{49}$ Barreiro Fernández, Ha Contemporánea de Galicia, TI, 1982, pág.174-177.

${ }^{50}$ Fernández Casanova, $\mathrm{M}^{\mathrm{a}} \mathrm{C}$, La Sociedad Económica de Amigos del País de Santiago en el siglo XIX.
} 
Las Actas del ayuntamiento nos informa de su actividad:

"Se presenta D. Pedro Ventura de Puga a ofrecerse con su destino de Diputado de provincia ofreciéndose a la Corporación y lo que considere pueda ser útil a la parte de Prov a que corresonde". El ayuntamiento responde que "así esperaba de su acendrado patriotismo".

Se le encarga, el 22 de febrero de 1822, se ocupe de encargar una lápida sobre la Constitución de suscripción popular y también una "representación" sobre el salario del pregonero de la Diputación Provincial. Un mes después Pedro V. avisa de "haver ajustado la lápida en comp ${ }^{a}$ de los Sres. Marqués de Almeiras, Pestaña y Srio. de la Diputación" cuyo coste asciende a 1900 reales, por lo que el ayuntamiento le da las gracias.

Podemos decir que Pedro Ventura forma parte de los "hidalgos liberales que comprendían que fortaleciendo una tendencia muy moderada dentro del liberalismo resultarían a la larga beneficiados" (Barreiro Fernández, 1982).

$\mathrm{O}$, que, en todo caso, lo que importa es estar en el poder y controlar sus resortes.

Sin embargo, la duración del período constitucional es breve y la restauración del absolutismo cambia las cosas:

El 17 de julio de 1823 se produce la reposición de los ayuntamientos anteriores al 17 de marzo de 1820 y los antiguos regidores orensanos se posesionan de sus cargos. No aparece entre ellos Pedro Ventura de Puga lo que resulta bastante significativo. Los regidores repuestos son: el marqués de Villaverde, D. Antonio Arias, D. José Losada, d. José Varela y D. Antonio Saco. Representan "el espíritu del absolutismo y del futuro tradicionalismo" (Otero Pedrayo, 1960).

La entrada de las tropas francesas en Ourense se realiza el día 20 de agosto y es entonces cuando se inician las depuraciones y persecuciones, y son arrancadas las lápidas de la Constitución, símbolo del liberalismo.

Es en este contexto, en el que hay que entender el documento del 2 de agosto de 1824 en el que D. Pedro, ante el escribano Fernández Villadóniga, afirma ignorar haber sido nombrado individuo de la Diputación:

"sin tener la menor noticia de semejante nombramiento hasta haberse publicado en los papeles públicos de aquella época mi nombre como tal individuo (...) yo jamás había dado pruebas de afecto a la llamada Constitución, antes vien en conversaciones particulares habia vituperado el modo violento con que se habia planificado y las malas consecuencias que resultarian de los defectos de la misma, cifrando solo mi bienestar en ser un vasallo pacifico, en dedicarme a los cuidados domesticos (...)... en aquella fatal epoca (pedía) a Dios por el bien de mi pais, porque se restableciese 
el orden y la tranquilidad, y porque proporcionase al Rey nuestro señor los medios mas eficaces y prontos de poner las cosas en el estado natural y feliz que conocieron nuestros antepasados" 51 .

En este mismo documento, los testigos citados por Pedro V. indican que éste no quería ser nombrado individuo de la Diputación y que sólo asistía a las juntas si lo obligaban con sus llamamientos, y "que no era un panejirista de la tal Constitución".

Desde finales de septiembre de 1824 a finales de noviembre, Pedro Ventura está ausente de su casa de Fontefiz aunque su mujer sí permanece. Es posible que esta ausencia esté relacionada con la turbulenta situación política.

No tenemos noticias de actividades públicas de Pedro Ventura en el período que sigue, de la década ominosa.

En el año 1827 encuentra problemas para seguir gozando de su estado privilegiado, ya que los vecinos del Coto de la Barra "acaban de negar el estado de nobles a todos los que por tales estaban reconocidos antes". Debido a esto realiza varias consultas para conseguir carta de posesión y propiedad de la nobleza y presenta una serie de alegatos para obtener la ejecutoria.

Parece ser que en este año se multiplican las pruebas de hidalguía (Otero Pedrayo, 1953).

En estos últimos años del reinado de Fernando VII, Pedro Ventura no asiste con mucha frecuencia a las sesiones municipales, según se desprende de una nota que el ayuntamiento le envía en 1832:

..."se sirva concurrir a los Ayuntamtos. que se celebren como Rexidor perpetuo del mismo de qe se halla posesionado y desempeñar las demás funciones anexas a dcha. Rexidoría"...

Ante lo cual se disculpa alegando.

..."que siempre fue muy lisonjero y lo sera hasta que muera el contribuir por mi parte a qto. Pueda hacer la felicidad de Orense de su provincia y haun de Galicia toda, Po. El cuidado de mis haciendas, las obligaciones domesticas (...) me imposibilitan (...); mas todas las veces que pueda concurrire”.

Alude también a su edad "ya bastante adelantada". Tiene 57 años en este momento.

${ }^{51}$ AHPOR, C 9706 
En el año 1833 se le encarga, junto con el marqués de Villaverde, felicitar a Fernando VII por la mejoría de su enfermedad, pero el viaje no llegó a realizarse por la enfermedad del propio Pedro Ventura.

La instauración del régimen liberal en 1833, vuelve a proporcionarnos noticias de sus actividades políticas, y también de las de su yerno, D. José de Montenegro, marqués de Leis (aunque su título no esté muy claro en estos años), quien ya en 1820 inicia sus actividades, como coronel de Milicias, apresando al jefe de los absolutistas, barón de Santijuani.

A fines de diciembre se celebra en Ourense la proclamación de Isabel II, en la cual "ordenó todas las funciones el marqués de Leis".

José de Montenegro tiene una destacada intervención en la vida municipal orensana durante el período liberal: en 1834 se le nombra Capitán de la Milicia Urbana, por ser persona "de conocida adhesión a la causa de Isabel II. En 1835 preside como alcalde el ayuntamiento de matiz liberal. La marquesa de Leis, hija de Pedro Ventura, contribuye junto con otras "damas de la primera aristocracia", al pago de camisas para los nacionales. Así que los marqueses de Leis están claramente en contra de la causa carlista. De todas formas, su adscripción política debe ser el moderantismo ya que en 1836 el jefe político de Ourense "mandó borrar (de la milicia orensana) quizá por poca adhesión al movimento de la Granja, al marqués de Leis". José de Montenegro sale elegido senador en las elecciones de 1837 (Otero Pedrayo, 1953).

\section{- 1834: Comisario de Millones y Diputado a Cortes}

En lo que respecta a Pedro Ventura de Puga, a principios del año 1834, es elegido por el Ayuntamiento de Ourense, Comisario de Millones para lo cual deberá trasladarse a la ciudad de A Coruña. Desde aquí realiza varias gestiones relacionadas con el "Repartimiento" por encargo del ayuntamiento de Ourense en los meses de febrero y marzo.

En mayo de este mismo año es elegido diputado a Cortes. El Estatuto Real, aprobado el 10 de abril de 1834, establecía que los procuradores debían de ser españoles, mayores de treinta años y poseer una renta anual de 12.000 reales.

Pedro Ventura, con 59 años, formará parte de los 188 procuradores que componen este estamento, quienes, aunque elegidos por tres años, estarán sólo dos, ya que en 1836 con el Motín de La Granja termina la vigencia del Estatuto Real. El propio Pedro V. nos informa de su elección:

"El año 34 volví a ser nombrado procurador a Cortes y arrastrando los efectos del cólera me presenté en Madrid antes de la instalación y asistí a ella siete meses consecutivos, hasta que se me concedió licencia para retirarme". 
De su actividad en las Cortes, en esta época en que se inicia en España el régimen liberal, sólo sabemos que participó en la "Comisión encargada de informar sobre el proyecto de Ley acerca de la enagenación forzosa por motivos de utilidad pública", en enero de 1835.

Es difícil, por lo tanto, pensar que estuviese vinculado al carlismo y que fuera "ultraconservador".

De los años posteriores sabemos que colaboró con el gobernador político de la provincia de Ourense. En 1842 envía un informe al gobernador sobre el cultivo del tabaco en la zona de Bande y los problemas de los "pueblos mixtos" en la frontera entre Galicia y Portugal.

En 1846 ayuda a "mantener el Orden público y el respeto debido a la Constitución y a las leyes que los sublevados desconocieron en Lugo ${ }^{52 ", ~ s e g u ́ n ~ c o n s t a ~ e n ~ l a ~}$ carta de agradecimiento de la Reina, durante el levantamiento que se inició en esta ciudad. De esta manera su actividad política se decanta claramente hacia el moderantismo.

Por último, en 1848 contribuye a la puesta en marcha de un depósito de caballos sementales en Xinzo de Limia, junto con su yerno el marqués de Leis. La mejora de la ganadería caballar es una de las preocupaciones de Pedro Ventura como veremos más adelante en su faceta de ilustrado.

Quizá como reconocimiento a su labor, es nombrado al año siguiente Comisionado regio para la agricultura en la provincia de Ourense. Cuenta en este momento con 73 años.

Lo que parece claro es su participación en el régimen liberal dentro del sector moderado. Su proyección política se inclina claramente hacia el moderantismo.

\section{PENSAMIENTO ECONÓMICO Y POLÍTICO: LA HERENCIA ILUSTRADA}

Como hombre nacido en el siglo XVIII, Pedro Ventura de Puga se mueve dentro de los esquemas de la Ilustración. Los ilustrados confían en la capacidad de la cultura para transformar la sociedad, se dirigen a las clases dominantes y a los poderes públicos y consideran que con la difusión de nuevos conocimientos es posible lograr una sociedad mejor ${ }^{53}$

\footnotetext{
52 Agradecimiento de la Reina... AHPOR, C 9706, 18 abril 1846.

${ }^{53}$ F. Dopico, A ilustración e a sociedade galega. A visión de Galicia dos economistas ilustrados, 1978.
} 
La obra de Pedro Ventura consta de un Informe dirigido a la Real Junta de Comercio de La Coruña en 1832, de una Memoria escrita en 1843, cuando tiene 68 años, que será publicada en la revista: "Galicia, revista universal de este Reino" en los años 1861 y 1862 (es, que sepamos, el único escrito publicado en su época); Y de un manuscrito sin fecha titulado: Origen y facultades del reino de Galicia .

Además, contamos con breves notas sobre cuestiones concretas como los foros, la instrucción pública o la cría de los gusanos de seda.

\section{- Informe sobre Galicia para la Real Junta de Comercio (1832)}

El Informe ${ }^{54}$, dado a la Real Junta de Comercio en el año 1832, parte de un punto de vista que aún resulta actual en la Galicia de hoy: la importancia de las comunicaciones. Sin embargo, por las soluciones adoptadas se queda desfasado incluso para su época ya que no se hace ninguna mención al ferrocarril (que su autor debió conocer en su estancia londinense), aunque quizá, dada la penosa situación de las comunicaciones en Galicia, fuera utópico pensar en ello. Las vías de comunicación propuestas son caminos y canales. La agricultura junto con la industria ("las artes") constituyen la base de la economía gallega. Veamos brevemente los aspectos tratados:

Galicia tiene condiciones "para ser feliz": puertos numerosos, población abundante, clima adecuado y "aplicación y agudeza en los naturales". La causa de su atraso es la falta de "impulso y movimiento"; los caminos son fundamentales "para la industria agrícola y fabril" pero Galicia, en este punto, se halla "en estado de naturaleza".

La agricultura cobraría nueva vida gracias a los caminos. Centeno, maíz, patatas y castañas lograrían aumentar su producción. El vino, antes exportado a Inglaterra, podrían volver a comercializarse a través de los "caminos de ruedas" a lo largo de las riberas de los ríos. Con el olivo, afectado por una plaga "incurable hasta el presente" se abastecería a la mayor parte de Galicia. Las plantas textiles presentan grandes posibilidades, hay que potenciar el cultivo de moreras y la cría de gusanos de seda y el de la rubia para tintes.

La industria no puede prosperar sin el "apoyo de las ciencias naturales y exactas"; la industria de la lana se puede desarrollar con la materia prima procedente de León y el perfeccionamiento de la técnica: hilado, tejido y tintes. El algodón tiene también posibilidades gracias a las posesiones ultramarinas que proporcionan la materia prima a los puertos gallegos y a la introducción de maquinaria. Y, por último, la industria de la seda presenta la ventaja de poder emplear a mujeres y niños en la

\footnotetext{
${ }^{54}$ Memoria que paso a esta R1 Junta en 27 de febrero de corr.ete año el Dr. D. Pedro V. de Puga caballero hacendado vecino de la cuidad de Orense. El borrador manuscrito de este informe se halla en el AHPOR C 9706, y fue publicado íntegro por Ferro Couselo en el Boletín Auriense T.III, 1973. El original está en poder de Carlos Martínez - Barbeito y fue consultado gracias a su amabilidad. Este mismo autor ha publicado una síntesis del citado informe en "Economistas gallegos del pasado 1700-1900".
} 
cría del gusano; en lo que respecta al lino, se remite al informe de otro ilustrado, Cónsul Jove, presentado también a la Junta de Comercio.

Destaca la mala calidad del aguardiente por su fabricación defectuosa, indica que sólo conoce la existencia de una alquitara "la que hay en la ciudad de Orense en poder de Dn. Josef Riol" que destila un aguardiente exquisito.

Finalmente señala la importancia de la enseñanza: los Hospicios deben convertirse en un "semillero de las artes" y enseñar oficios a mendigos, niños expósitos, delincuentes...; en este aspecto coincide también con otros ilustrados.

Concluye el texto con optimismo: "Con este cambio se acabaría la distinción de partidos, pues que el hombre que reúne una ocupación lucrosa a un bienestar proporcionado a su clase y circunstancia se opone a toda revolución que pueda cambiar su estado próspero y seguro por otro incierto y probablemente miserable".

Pedro Ventura de Puga es un ilustrado reformista, incluso reformista muy moderado ya que ni siquiera es consciente “do excesivo peso das cargas feudais" (F. Dopico, 1978), es más, no encuentra más que ventajas en el sistema foral, como veremos luego.

Para él, es posible solucionar el atraso de Galicia con la construcción de vías de comunicación con lo que aumentará la producción agrícola, y difundiendo métodos y técnicas para mejorar la industria, pero sin alterar la estructura social. No debemos olvidar que la base de la economía de la casa de Fontefiz son las rentas de origen agrario.

\section{- Memoria sobre Galicia presentada ante la Real Sociedad Económica de Santiago}

La Memoria ${ }^{55}$ que presenta ante la Sociedad Económica de Santiago, como antiguo socio corresponsal de la misma, la escribe en 1843 cuando cuenta 68 años, y continúa con el mismo tono optimista. En algún aspecto, casi podríamos calificarlo de arbitrista ya que algunas de las medidas propuestas están lejos de la realidad. La Memoria consta de 13 proposiciones que resumiremos brevemente:

Considera, en primer lugar, que la ciudad de Santiago de "feliz posición topográfica”, debe ser la capital de Galicia; hay que comunicarla por tierra con las restantes ciudades gallegas y con la Corte. "Sólo falta comunicarla por mar, (lo cual se logra-

\footnotetext{
55 Memoria que trata de las trece proposiciones que comprende el párrafo de los conocimientos científicos e industriales del programa de la Sociedad de 23 de abril del presente año 1843, escrita y presentada por D. Pedro Ventura, antiguo socio corresponsal de la misma.

Galicia, revista universal de este Reino. Año II, Coruña, $1^{\circ}$ de diciembre $1861, \mathrm{n}^{\circ} 29$ y Año III, 1 de marzo de $1862, \mathrm{n}^{\circ} 5$.

Tengo que agradecer a Antonio Meijide Pardo el hecho de proporcionarme este dato.
} 
ría) fácilmente sin grandísimo coste por medio de un canal que se abra desde el puente de la Rocha hasta unirlo con el río Ulla en el puente de Cesures". De esta manera, gracias a la introducción del carbón asturiano para mover la maquinaria y la creación de fábricas e institutos, llegaría a ser la "segunda Barcelona de la península".

La primera proposición trata de los foros, cuestión que "no necesita a mi entender variación alguna”. Introduce únicamente alguna modificación en el caso de los prorrateos para reducir las cargas del cabezalero. Ya en otro texto anterior, del año 1819, Pedro Ventura se mostraba partidario de los foros porque "con esto pasan a la circulación general y se cultivan mejor (las tierras)siendo esta la principal causa de hallarse Galicia mas abentajada a las demas provincias de España en Agricultura y población."

La mejora del ganado vacuno, caballar y mular es posible si se crean paradas que produzcan "crías hermosas" y mejoren la raza. Alude a la parada de caballos de Xinzo da Limia que funcionó durante el reinado de Fernando VII pero ya no en la actualidad. Y en lo que respecta al ganado vacuno, lanar y de cerda que proporcionan carne y cueros, propone que se le de "un premio de consideración al que descubra el medio poco costoso de quitar el gusto salado y curado a las carnes y devolverlas al estado de frescas", de esta manera se podrían exportar.

Acerca de la industria textil, analizada en las proposiciones $4^{\circ}$ y $5^{\circ}$, repite argumentos del informe de 1832. Trata de su organización en dos niveles: doméstico e industrial sin que esto suponga una contradicción: "el establecimiento de fábricas en grande (...) no llegaría a arruinar enteramente la industria popular de los lienzos en Galicia". Resalta la necesidad de introducir maquinaria "para poder sufrir la concurrencia de los mercados extranjeros".

La mejora de los transportes, vital para el desarrollo de la industria, comercio y agricultura, sería una realidad no sólo con el canal de Santiago, sino también haciendo navegables el Miño y el Sil.

Cita dos ejemplos para probar "que Galicia es a propósito para la producción de la seda: el del marqués de Santa Cruz, abuelo del actual, que plantó moreras y crió gusanos cuyo hilo fue hilado por valencianos llegados expresamente para ello a su quinta; después el hilo se tejió en Valencia y con la tela adornó su casa”. También Pedro Ventura realizó el proceso en su casa, donde tenía una morera blanca, pero no llega a producir hilo. "mande venir semilla de gusanos de Valencia: meti el papel en que estaba pegada en el cajón de una mesa (...) y vi que los gusanitos..."

Ejemplos que se quedan en el plano meramente anecdótico.

Intenta también propagar el cultivo de la alfalfa, pero los resultados no son positivos: crece tanta hierba de las especies gramíneas que debilitan el crecimiento de la alfalfa y llegan a sofocarla. Concluye que en Galicia se puede sustituir esta planta (que debe darse sólo en terrenos arcillosos) por los prados naturales.

Para la emigración, motivada por la falta de trabajo en Galicia, encuentra una solución ya aludida en el anterior informe: los hospicios, concebidos no como cárceles, sino como seminarios de artes y oficios.

Otros apartados aluden al exceso de contribuciones y a la necesidad de obtener datos estadísticos fiables "para que todos los españoles contribuyan a sostener el Estado con proporción a los intereses de cada uno”. En lo referente a educación propone el plan de estudios ideado por el Duque de Rivas. 
Y por último, concluye con la necesidad de escribir una historia de Galicia. Expone ideas desarrolladas en el manuscrito sobre la Junta del Reino de Galicia.

Pedro Ventura de Puga, al igual que otros ilustrados gallegos, propone remedios para lograr un desarrollo económico, se preocupa por las comunicaciones, la difusión de la ciencia y la técnica, la lucha en contra de la población improductiva, mostrando así su inquietud por los problemas concretos de su país. Naturalmente son preocupaciones que se quedan en el plano de la teoría ya que sin modificar las relaciones de producción no es posible una transformación económica, y estas continúan siendo intocables ${ }^{56}$.

Sin embargo, en sus escritos aparece una clara preocupación por la instrucción pública y lleva adelante gestiones para potenciar la educación. Propone a las Cortes y a la Diputación (según se desprende de una carta suya), la creación de un instituto en el que se impartirán: "matemáticas, física experimental, química con sus aplicaciones, mecánica, dibujo lineal y natural y, acaso, geografía física y comercial (...) dejando para mas adelante cuando la provincia prospere la economía política, literatura y mas ciencias de adorno y lucimiento".

Para conseguir esto considera necesario la colaboración de los diputados y senadores de la provincia e incluso de "Fontán, como hombre científico, orador gallego y amante de la instrucción y del saver". Domingo Fontán era catedrático e industrial y fue secretario de la Diputación Provincial de Galicia durante el trienio constitucional. En 1814, en plena época de depuraciones políticas, se solicitó la suspensión de tres profesores de la Universidad de Santiago entre los cuales se hallaba Domingo Fontán (Barreiro Fernández, 1982).

\section{- Origen y facultades del Reino de Galicia}

\section{(Manuscrito de Pedro Ventura de Puga, sin fechar)}

"Reflexiones y apuntes que ofrece a quien escriba la historia de Galicia en sus cuatro ramos, militar, religioso, civil y político un gallego amante de su pais, entre los que pueda sacar de los archivos de las 7 capitales que fueron las 7 provincias del antiguo Reino de Galicia, de sus monasterios, cabildos y de alguno de Grandes de España."

La historia militar y política de Galicia antes de la irrupción de los sarracenos debe estar envuelta entre tinieblas; al tiempo de la conquista pudieron venir tan furiosos, por la resistencia que acaso le harían los gallegos de aquellos tiempos, que devieron haver arrasado y quemado todos los pueblos de alguna consideración, y haver perecido con ellos todos los escritos y noticias que huviese en el pais, no solo de los tiempos de la dominación romana, y haun anteriores, sino de goda; si algun escrito pudo escapar de aquella catastrofe debe estar en algun archivo antiguo acaso hecho polvo o deteriorado de modo que no sea posible leerlo. Solo en Oviedo, o en

${ }^{56}$ F. Dopico establece una clasificación entre los ilustrados gallegos en función de su posición ante las relaciones de producción dominantes. Los abolicionistas o avanzados plantean la incompatibilidad de las relaciones de producción feudales y el desarrollo económico, un ejemplo sería Lucas Labrada. Los reformistas, como Somoza de Monsoriú, Cornide o Cónsul Jove, proponen la racionalización del sistema productivo y suavizar las condiciones de vida del pueblo. Op. cit., págs. 21 y ss. 
algun otro archivo de Asturias donde no pudieron llegar los sarracenos y en Simancas, podrá haver algun escrito que diga lo que fueron los Godos gallegos, la resistencia que hicieron a los Moros, y que costumbres eran las que reinaban entre ellos por aquellos tiempos. Como los Arabes por la conquista que hicieron de los paises cientificos del Egipto, y mas posesiones Romanas civilizadas por los Griegos se civilizaron tambien ellos con la lectura de su(s) obras maestras y a la vista de tan preciosos monumentos, como dejaron antes de su degeneración y decadencia, podrá ser que en los archivos de Sevilla, Cordova y Granada hayga escritos arabes que digan lo que eran las provincias de España antes de que ellos las conquistasen, las noticias alcanzaran tambien a Galicia. En el Monasterio del Escorial y su librería, tengo entendido, que havia muchos codices arabes ineditos, que si no fueron arrebatados por los franceses del tiempo de Napoleón, daran a caso alguna noticia que se desean respecto a Galicia.

Desde el principio de la restauración de la monarquia Goda, que debe comenzar desde la prima. batalla ganada a los sarracenos en Asturias, devio continuar el gobierno feudal establecido como antes de la invasión; a medida que fueron conquistando paises, lo fueron restableciendo; y repartiendo los Reyes los tenemos entre los gefes y oficiales del exercito y el clero; de esta disposición adoptada general te. por todos los monarcas y Gefes supremos de la fuerza armada en aquellos tiempos proviene el que toda la tierra de Galicia, con pocas excepciones, pertenezca su dominio directo a grandes de España descen tes. de aquellos gefes primitivos y al clero secular y regular. Concluida o suspendida la guerra, se desacian los exercitos y cada gefe retirado a su feudo o dominio era cuasi independiente y governaba su estado y vasallos, que se lo cultivaban y hacian producir, como soberano; no reconociendo al Rey, que tambien vivia de sus estados particulares, pa. nada, hasta que llamados a reunirse pa. continuar la guerra volvian a su obediencia solo en la parte necesaria pa. conservar lo que ahora se denomina disciplina militar, aunque supongo no tan rigurosa como la moderna.

Después estos mismos señores con los gastos que hacian en la guerra y con el lujo que se introdujo entre ellos inspirado por el que tenian y veian en sus mismos enemigos, se vieron precisados a ceder parte de sus terrenos a allegados suyos y amigos con la carga de asistirlos en la guerra con cierto num ${ }^{o}$ de hombres armados o con pensiones que les imponian un provecho del $S^{o}$ r. Estos nuevos propietarios unos por acciones distinguidas en la guerra iban ensalzando su condicion hasta cuasi nivelarse con los mismos de quien eran favorecidos, y otros con sus ahorros que les proporcionaban metalico con que iban ganando tambien considera ${ }^{o} n$ y riquezas, que los elevaban fuera de la esfera comun; de esta circunstancia se fue originando esta segunda nobleza que con mas o menos vicisitudes fue llegando hasta $n t^{o}$ s dias.

El alto clero, que tambien era participe de parte no pequeña de las conquistas, cargaba tambien con la obligación de mandar a la guerra el num ${ }^{\circ}$ de soldados que se les imponia; de esta obligación provino el que varios prelados concurrian a la guerra en persona mandando su contingente guerrero, hasta las mismas regulares, huvo tiempos, en que tuvieron que concurrir a la guerra con sus respectivos contingentes, segun lo atestiguan varias pinturas antiguas de monjes benitos a caballo en aptitud guerrera.

De esta independ ${ }^{a}$ en que vian (sic) las clases pudientes, y de las guerras conti- 
nuas que se sostenian contra los sarracenos se origino la necesidad de pedir interes $p^{a}$ costearla en clase de donativo; pues no siendo asi no se concederian por no perderla. Para consentir en darlo y ver las razones que se alejaban $p^{a}$ pedirlo fue preciso reunir en Juntas los contribuyentes a el, que en Castilla y Aragon se llamaron Cortes, en Vizcaya y Asturias Diputaciones y en Galicia Juntas de Reino. Los individuos que en un principio pudieron concurrir a ellas pudieron ser los Sres feudales seculares y eclesiasticos, como amas propietarios, y sobre quienes devia recaer el donativo, $p^{o}$ andando el tiempo, y repartida la propiedad por medio de los foros, creado y dada consistencia el gobierno municipal de los pueblos reunidos, con especialidad a las siete ciudades de Galicia caveza de otras tantas provincias, animado algo el trafico, y aumentada la población y la agricultura, quedaron solo con derecho de asistir a estas juntas los siete diputados de otras tantas ciudades que havia en Galicia que eran La Coruña, Santiago, Tuy, Lugo, Mondoñedo y Betanzos, como representantes de las clases pudientes y que devian contribuir al donativo; pues que los individuos de los ayuntam tos. eran los mismos señores feudales tanto eclesiasticos como seculares o sus representantes y algun otro cuyo derecho deriba de ellos por eso eran y se llamaban regidores perpetuos.

Esta Junta de reino reunida en La Coruña concedia o negaba lo que pedían los Reyes, en el primer caso imponia las condiciones que les parecian mas razonables sobre el modo de invertir lo pedido, y tiempo en qe. devia verificarse el aporte, nombrando desde el momento un depositario que era siempre un individuo de alguno de los siete ayuntam.tos, quien conforme se iban reuniendo los caudales daba noti(ci)a a la Corte pa. que se dispusiese(n) los libram.tos hasta agotar lo concedido. La misma Junta al paso que se reunia pa. esta concesion revisaba las Rs. Ordenes expedidas desde la última junta, mandaba circular y obedecer las que consideraba utiles al pais suspendia la publicación de las que juzgaba dañosas representando los perjuicios que de obedecer le resultarian, cuyas observaciones siempre eran acatadas, pa. congraciar y agradar a la Junta, pa. que la primera necesidad de otro pedido se mostrase generosa en concederlo. Tambien pedia al monarca el qe revocase Rl Ordenes espedidas y que se dictase otras que fuesen convenientes a los intereses necesarios pa. llevarlas a efecto; estos deseos eran siempre satisfechos por no agraviar ni descontentar a los contribuyentes. En el archivo de las Juntas del Reino que esta dentro de la sala donde se halla el ayuntamiento de La Coruña hay actas de algs. Siglos que compruevan lo que va dicho, y en que se ven escritos bastante luminosos pa aquellos tiempos, en qe se ventilan disposiciones utiles y ventajosas al pais y es una lastima que no hubiese un escritor qe registrando el archivo de la Junta y los de las siete ciudades y haun de los cavildos y antiguos monasterios donde se hallarian preciosos materiales no tratase de componer una hermosa y util historia civil militar y politica de Galicia, con que se podrian componer las antiguas franquicias y libertades que disfrutaron ntros padres, dimanadas de costumbres adquiridas en fueros concedidos por ntros antiguos Reyes, o por pactos tacitos o expresos entre el Monarca y los subditos, y con lo que se hacia ver que las que dimanan de la Constitución vigente no son sino la renovación de las antiguas malam.te perdidas y olvidadas. Desde que la casa de Austria vino a reinar en España las libertades que disfrutaban Castilla y Aragon y las demas provincias del Reynno fueron siempre en decadencia, era pues con- 
siguiente que decayese (n) tambien y se minorasen las facultades de la Junta del Reino de Galicia; reunida a la presencia del genl. qe mandaba la provincia con residencia en La Coruña no podia deliberar con la libertad que lo hacia antes. Desde la batalla de Villalar la Corte devio estar celosa de las corporaciones particulares que representaban las provincias y devio por tanto hacerlas ... por sus... en las provincias pa. evitar otras asonadas...La referida en este estado, y... alucinados los gallegos o mas bien las municipalidades con el brillo esterior con que se tenia...contes de Castilla y con las gracias y empleos que se daban a los diputados, que asistian a ellas como premio de la deferencia que tenian con lo propuesto por la corte, por eso es que tratan de pedir en tiempo de uno de los felipes la entrada en las cortes de Castilla, logrando solo que se les conceda un boto... solo como tenian varios villorrios de Castilla, mezquina concesion pa. cien mil ducados que costo el donativo de Galicia pa. conseguirlo; según todo consta de la cedula de concesión que original se halla en el archivo de la Junta del Reino. Desde esta epoca ... apenas mas Juntas del Reino que de seis en seis años pa. el nombramiento de los regidores que devieron tener mas energia pa. defender sus fueros y privilegios y acaso tambien por ser mas popular su representancion e interes a ... en ella a lo qen.l de las masas.

\section{CONCLUSIÓN}

El último señor de Fontefiz hereda un patrimonio importante lo que le permite vivir de rentas. Es un hombre ligado al campo y a sus tareas: el cobro del maíz, trigo, centeno, castañas, la vendimia, la elaboración del vino, la realización de prorrateos, los contratos de aparcería y el cobro de deudas. Vive en el pazo hasta que, ya mayor, se traslada a la ciudad de Ourense.

Participa activamente en la política durante la guerra de Independencia y en la época liberal, tanto a nivel municipal como regidor del ayuntamiento de Ourense, como diputado a Cortes.

Considera, como otros ilustrados, que es posible mejorar la situación económica de Galicia manteniendo una sociedad de privilegios y los foros.

Por lo tanto, no encuentra contradicción entre la colaboración con el régimen liberal y el mantenimiento de sus privilegios "mi nobleza hereditaria".

Pedro Ventura de Puga vivió entre el siglo XVIII y el XIX, como hombre de su tiempo participa de las ideas ilustradas y del liberalismo, en ambos campos en el sector moderado. Se incorpora sin problemas a las nuevas condiciones políticas del siglo XIX, ya que se siguen manteniendo las arcaicas estructuras del Antiguo Régimen.

Habría que analizar hasta que punto la participación de la hidalguía en la vida política supuso un lastre, y en qué medida, para la evolución política de Galicia. 


\title{
10. CUADROS: ÁRBOL GENEALÓGICO DE INÉS DÍAZ DE CADÓRNIGA
}

Cuadro $n^{\circ} 1$

\section{ÁRBOL GENEALÓGICO DE INÉS DÍAZ DE CADÓRNIGA}

\author{
JUAN FERNÁNDEZ DE TOUBES Y TEMES $\leftarrow$ ELVIRA DÍAZ DE CADÓRNIGA \\ $(† 1592)$ \\ $\downarrow$ \\ INES DÍAZ DE CADÓRNIGA \\ (Escritura de fundación del vínculo) \\ $\downarrow$ \\ ELVIRA DÍAZ DE CADÓRNIGA \\ (escritura de dote de 1606) \\ $\downarrow$ \\ $\downarrow$ \\ Hasta \\ Pedro Ventura de Puga
}

Elvira Díaz de Cadórniga falleció en 1592 según el P. Crespo. Sus padres eran señores de Villanueva de la Barra. Actualmente podemos ver la siguiente inscripción en la iglesia de Santa María de la Barra (pared lateral del ábside):

"Esta obra mando hacer a su costa Elvira Díaz de Cadórniga muger Qe fue de $\mathrm{Iv}^{\circ}$ Fernández de Toubes. 1586"

Inés Díaz de Cadórniga aparece en el Memorial de 1668 como sucesora de su madre.

"Si saben que dicha Inés Díaz de Cadórniga estubo casada con Grego de Noboa Villamaría legitimam.te la cual hiÇo vinculo y mayorazgo de dichos vienes que llevab a su muerte y del tercio y quinto (...) por su hija legítima a Elvira Diaz de Cadorniga que fue heredera de dicha su madre y sucesora en el vínculo por aver muerto sin sucesion legitima Jv.n y Greg ${ }^{\circ}$ de Noboa sus hermanos hijos tambien de la dicha fundadora"

Memorial de 1668, AHPOR C9633 n 130.

Elvira Díaz de Cadórniga, de igual nombre que su abuela, será la sucesora y es la que convierte Fontefiz en una casa solariega. Ya en 1606 la encontramos en Fontefiz, lugar que recibe como dote. Con ella se produce el traslado desde San Ginés de la Peroja a Fontefiz.

Línea de descendencia femenina : desde Inés Díaz de Cadórniga que en 159- hace escritura de fundación del vínculo y cuyo marido, Gregorio de Novoa se afana en consolidar su situación de noble. (Información de nobleza de Gregorio de Novoa Villamaría, 1597. Copia del año 1700. Esta Información se extrae a partir de una querella en la que Gregorio de Novoa y su hemano Francisco, acusan a un criado del primero de dejar preñada a una sobrina del mismo y por ello es condenado a doce años de galeras. 
Cuadro $n^{\circ} 2$

\title{
ÁRBOL GENEALÓGICO DE GREGORIO DE NOVOA VILLAMARIN
}

\author{
PEDRO DE BÓVEDA Y QUIROGA El viejo $\leftarrow \rightarrow$ LEONOR DE NÓVOA VILLAMARÍN \\ TRISTAN DE NÓVOA El viejo \\ $\leftarrow$ TERESA VÁZQUEZ DE TOUBES \\ PEDRO DE BÓVEDA NÓVOA \\ $\leftarrow$ FRANCISCA VÁZQUEZ DE PUGA \\ $\downarrow$ \\ GREGORIO DE NÓVOA $(\dagger 1621)$ : \\ $1^{\circ}$ matrimonio: Catalina López Moure \\ $2^{\circ}$ matrimonio: INÉS DÍAZ DE CADÓRNIGA
}

De este segundo matrimonio nacen:

Juan de Novoa, Gregorio de Novoa y Cadórniga, María Díaz de Cadórniga, Ana de Nóvoa, Francisca Vázquez de Puga y ELVIRA DÍAZ que será la sucesora de su madre

$\begin{array}{lc}\text { ALONSO VÁZQUEZ VARELA } & \leftarrow \text { ELVIRA DÍAZ (dote de 1606) } \\ & \downarrow \\ \text { FRANCISCO DE PUGA } & \leftarrow \text { BENITA DE NÓVOA } \\ \downarrow & \text { ANTONIO DE PUGA } \\ & \downarrow \\ & \text { RODRIGO DE PUGA } \\ & (\text { Testamento 1756) } \\ & \downarrow \\ & \text { PEDRO VENTURA DE PUGA, } \\ & \text { el mayor } \\ & \downarrow \\ & \text { RAMIRO DE PUGA (†1804) } \\ \downarrow & \text { PEDRO VENTURA DE PUGA } \\ & (1775-1866) \\ & \downarrow \\ M^{\mathrm{a}} \text { MANUELA DE PUGA }\end{array}$




\section{BIBLIOGRAFÍA}

ADRIO MENÉNDEZ, José: Del Orense Antiguo (1830-1900), Ourense 1935.

ANES, Gonzalo: El Antiguo Régimen: Los Borbones, Madrid, 1957.

BARREIRO FERNÁNDEZ, X.R.: El carlismo gallego, Santiago,1976.

BARREIRO FERNÁNDEZ, X.R.: Liberales y Absolutistas en Galicia, Vigo, 1982.

BARREIRO MALLÓN, B.: "Las clases urbanas en Santiago en el S. XVIII: definición de un estilo de vida y pensamiento": $L a H^{a}$ social...1982)

CRESPO POZO: Blasones y linajes de Galicia, T.II-IV.

DÍAZ OTERO, ANTONIO: Orígenes, estructura y evolución de la Junta Suprema del Galicia, 18081813. Memoria de licenciatura, 1981, Santiago.

DOMÍNGUEZ ORTIZ, A.: Hechos y figuras del S. XVIII español, 1973.

DOMÍNGUEZ ORTIZ, A.: Sociedad y estado en el S. XVIII español, Madrid, 1981.

DOPICO, Fausto: A ilustración e a sociedade galega. A visión de Galicia dos economistas ilustrados, Vigo, 1978.

EIRAS ROEL, A.: Régimen subforal e hidalguía intermediaria (Prólogo a El dominio de San Martin Pinario ante la desamortización, Santiago, 1972.).

FERNÁNDEZ ALONSO, B.: Orensanos ilustres, Orense 1916.

FERNÁNDEZ CASANOVA, M.C.: La Sociedad Económica de Amigos del País de Santiago en el S. XIX: Ed. Do Castro, 1981.

FERNÁNDEZ VILLAMIL: Las Juntas del Reino de Galicia, Madrid, 1962.

FERRO COUSELO, J.: Ayer y hoy del pazo de Fontefiz. Orense, 1965.

FONTANA, J.: La quiebra de la monarquía absoluta 1814-1820, 1974.

FRAGUAS Y FRAGUAS, A.: Geografía de Galicia, Santiago, 1953.

GARCÍA LOMBARDERO, J.: La agricultura y el estancamiento económico de Galicia en la España de Antiguo Régimen, Madrid, 1973.

GARCÍA SANZ, A.: "Las tribulaciones de un noble castellano en la crisis del A.R.: D. Luis Domingo de Contreras y Escobar, V Marqués de Lozoya (1779-1838)": $H^{a}$ económica y pensamiento social, Madrid, 1983.

GOUBERT, Pierre: El Antiguo Régimen, 1969.

LEIRÓS FERNÁDEZ, M.: La junta de Galicia en el movimiento provincialista de la España de 1808. Tesis doctoral inédita, 1935.

MARTÍNEZ BARBEITO, C.: Torres, pazos y linajes de la provincia de la Coruña, 1978.

MARTÍNEZ MORÁS, F.: La Junta Superior de Subsidios, Armamento y Defensa del Reino de Galicia, A Coruña , 1955. 
MEIJIDE PARDO, A.: Gerónimo de las Casas (militar, científico y liberal gallego del S. XIX). A Coruña, 1975.

MEIJIDE PARDO, A: Escritores e autores na Galicia da ilustración, A Coruña, 1982.

MEYER, J.: La noblesse bretonne au XVIII siècle, Flammarion, 1972, París.

OTERO PEDRAYO, R.: "La reposición del A.R. en Orense en 1823", Cuadernos de Estudios Gallegos XXVI, 1953.

OTERO PEDRAYO, R: "Orense y las tierras orensanas en el S. XIX”, Cuadernos de Estudios Gallegos XV, 1960.

PORTELA PAZOS, S.: La guerra Independencia en Galicia, Santiago, 1946.

PUGA, P.: Memoria...: Galicia, revista universal de este Reino, La Coruña, 1861-1862.

RIVERA RODRÍGUEZ, M.T.: Los pazos orensanos, Ourense, 1981.

RODRÍGUEZ FERREIRO, H.: "La hidalguía rural del Morrazo en el siglo XVIII: análisis sociológico de un grupo dominante": La $H^{a}$ social de Galicia en sus fuentes de protocolos. Univ. Santiago, 1980.

SAAVEDRA, P.:Un aspecto de las crisis de subsistencia en la Galicia del A. R.: las ventas de tierras. Santiago, 1981.

TOMÁS Y VALIENTE, F.: El marco político de la desamortización. 1972.

VÁZQUEZ MARTÍNEZ, A.: El abad del Couto..., A Coruña, 1941.

"Los xefes de Alarma en la Guerra de Independencia en Galicia", Bol. Com. Monumentos de Orense, T.XIV, años 1943-44.

VILLÁN DE LA FUENTE, O.: "Crisis agrarias y transferencias de la propiedad: el gran invierno de 1710 reflejado en las ventas de tierra": La Ha social de Galicia en sus fuentes de protocolos. Santiago, 1980.

VILLARES PAZ, R.: Los prorrateos de tierras: su utilidad historiográfica, Santiago, 1981.

La propiedad de la tierra en Galicia 1500-1936, Madrid, 1982.

Foros, frades e hidalgos, Ed. Xerais, 1982.

Historia de Galicia, 1985.

VILLARROYA, T.: Breve $H^{a}$ del constitucionalismo español, 1976. 